\title{
Sensitivity of biogenic volatile organic compounds to land surface parameterizations and vegetation distributions in California
}

\author{
Chun Zhao ${ }^{1}$, Maoyi Huang ${ }^{1}$, Jerome D. Fast ${ }^{1}$, Larry K. Berg ${ }^{1}$, Yun Qian ${ }^{1}$, Alex Guenther ${ }^{2}$, Dasa Gu$^{2}$, \\ Manish Shrivastava ${ }^{1}$, Ying Liu ${ }^{1}$, Stacy Walters ${ }^{3}$, Gabriele Pfister ${ }^{3}$, Jiming Jin ${ }^{4}$, John E. Shilling ${ }^{1}$, and \\ Carsten Warneke ${ }^{5,6}$ \\ ${ }^{1}$ Atmospheric Science and Global Change Division, Pacific Northwest National Laboratory, Richland, WA, USA \\ ${ }^{2}$ Department of Earth System Science, University of California, Irvine, CA, USA \\ ${ }^{3}$ National Center for Atmospheric Research, Boulder, CO, USA \\ ${ }^{4}$ Departments of Watershed Sciences and Plants, Soils, and Climate, Utah State University, Logan, UT, USA \\ ${ }^{5}$ National Oceanic and Atmospheric Administration, Earth System Research Laboratory, Boulder, CO, USA \\ ${ }^{6}$ CIRES, University of Colorado, Boulder, CO, USA
}

Correspondence to: Chun Zhao (chun.zhao@pnnl.gov)

Received: 4 December 2015 - Published in Geosci. Model Dev. Discuss.: 19 January 2016

Revised: 29 April 2016 - Accepted: 10 May 2016 - Published: 27 May 2016

\begin{abstract}
Current climate models still have large uncertainties in estimating biogenic trace gases, which can significantly affect atmospheric chemistry and secondary aerosol formation that ultimately influences air quality and aerosol radiative forcing. These uncertainties result from many factors, including uncertainties in land surface processes and specification of vegetation types, both of which can affect the simulated near-surface fluxes of biogenic volatile organic compounds (BVOCs). In this study, the latest version of Model of Emissions of Gases and Aerosols from Nature (MEGAN v2.1) is coupled within the land surface scheme CLM4 (Community Land Model version 4.0) in the Weather Research and Forecasting model with chemistry (WRF-Chem). In this implementation, MEGAN v2.1 shares a consistent vegetation map with CLM4 for estimating BVOC emissions. This is unlike MEGAN v2.0 in the public version of WRF-Chem that uses a stand-alone vegetation map that differs from what is used by land surface schemes. This improved modeling framework is used to investigate the impact of two land surface schemes, CLM4 and Noah, on BVOCs and examine the sensitivity of BVOCs to vegetation distributions in California. The measurements collected during the Carbonaceous Aerosol and Radiative Effects Study (CARES) and the California Nexus of Air Quality and Climate Experiment (CalNex) conducted in June of 2010 provided an opportunity to evaluate the simulated BVOCs. Sen-
\end{abstract}

sitivity experiments show that land surface schemes do influence the simulated BVOCs, but the impact is much smaller than that of vegetation distributions. This study indicates that more effort is needed to obtain the most appropriate and accurate land cover data sets for climate and air quality models in terms of simulating BVOCs, oxidant chemistry and, consequently, secondary organic aerosol formation.

\section{Introduction}

Volatile organic compounds (VOCs) in the atmosphere play an important role in atmospheric chemistry, and therefore can significantly affect ozone and secondary organic aerosol (SOA) formation and ultimately air quality and climate (e.g., Chameides et al., 1992; Fehsenfeld et al., 1992; Andreae and Crutzen, 1997; Pierce et al., 1998; Poisson et al., 2000; Sanderson et al., 2003; Claeys et al., 2004; Arneth et al., 2010). Significant effort has been made on obtaining accurate predictions of atmospheric VOC concentrations; however, there remain large differences between observed and simulated values. These uncertainties result from many factors, including biogenic emission rates that are influenced by near-surface meteorological processes, sub-surface processes, representation of vegetation distributions and plant biology (Guenther, 2013) 
Biogenic emissions are a major source of VOCs (e.g., Zimmerman et al., 1978; Müller, 1992) in the atmosphere. In particular, isoprenoids (consisting mainly of isoprene and monoterpenes) that dominate biogenic VOCs (BVOCs) have been extensively investigated during the last 5 decades (e.g., Went, 1960; Rasmussen, 1972; Zimmerman, 1979; Lamb et al., 1987; Pierce et al., 1998; Niinemets et al., 1999, 2002; Arneth et al., 2007; Schurgers et al., 2009; Guenther et al., 1995, 2012). BVOC emissions were originally computed offline, producing prescribed emission inventories used by regional and global models (e.g., Huang et al., 2011). However, emissions of BVOCs depend on diurnal, multi-day and seasonal variations in light intensity, temperature, soil moisture, vegetation type and leaf area index (LAI) (e.g., Pierce et al., 1998; Niinemets et al., 1999, 2002; Arneth et al., 2007; Schurgers et al., 2009; Guenther et al., 2012). Therefore, various BVOC emission algorithms have been proposed that extrapolate limited laboratory and field measurements to prescribed regional and global ecosystems (e.g., Pierce et al., 1998; Niinemets et al., 1999, 2002; Arneth et al., 2007; Schurgers et al., 2009; Guenther et al., 1995, 2012). The uncertainties in biogenic emission schemes are mainly due to the scarcity of observations of BVOC fluxes and vegetation distributions over regional scales. Inappropriate coupling strategies between biogenic emission and land surface schemes may also introduce errors in estimating atmospheric BVOCs. For example, some models specify different vegetation distributions for biogenic emissions and landatmosphere interaction processes as applied in different parts of models.

BVOCs play a significant role in affecting the air quality and regional climate over California, where there have been many studies, such as the Carbonaceous Aerosol and Radiative Effects Study (CARES) (Zaveri et al., 2012) and the California Nexus of Air Quality and Climate Experiment (CalNex) (Ryerson et al., 2013), investigating the impacts of BVOCs and their interaction with anthropogenic pollutants. In the past 20 years, California's economy has grown rapidly and the population has increased by $33 \%$ (Cox et al., 2009). Although California has reduced the emissions of most primary pollutants, poor air quality still affects the well-being of millions of people. Nearly all Californians live in areas that are designated as non-attainment for the state (about $99 \%$ ) and national (about $93 \%$ ) health-based $\mathrm{O}_{3}$ and/or PM standards. Accurate predictions of $\mathrm{O}_{3}$ and $\mathrm{PM}$ concentrations are needed to develop effective attainment strategies, but this is complicated, in part, due to uncertainties associated with long-range transport of pollutants and local natural emission sources such as BVOCs.

In California, the complex topography and distribution of vegetation makes it difficult for models to capture the variability of BVOCs at regional and local scales. For example, Fast et al. (2014) showed that simulated biogenic emissions varied by as much as a factor of 2 within $8 \mathrm{~km}$ of an observation site in Cool, California. They also found that day- time mixing ratios of isoprene and monoterpenes from a regional simulation using the Weather Research and Forecasting model with chemistry (WRF-Chem) (Grell et al., 2005; Fast et al., 2006) are usually a factor of 2 smaller than the observations collected both at the rural Cool site and an urban Sacramento site. Conversely, simulated monoterpene mixing ratios were similar to observations during the day but by a factor of 3 too high at night at the observation site in Cool. They suggested that the biogenic emission rates calculated based on the Model of Emissions of Gases and Aerosols from Nature version 2.0 (MEGAN v2.0) might contribute to major biases in their simulations. Knote et al. (2014) also found that their simulations using WRF-Chem with MEGAN v2.0 produced BVOC concentrations that were too small over Los Angeles, and suggested that there might be deficiencies in the description of vegetation in urban areas. Thus, it is evident that uncertainties in simulated atmospheric BVOCs can arise from how well vegetation is represented in models. Furthermore, to our knowledge, none of the numerous chemical transport modeling studies for California have investigated the sensitivity of BVOC simulations to land surface schemes and vegetation distributions.

To better understand the uncertainties in simulating BVOCs associated with land surface schemes and vegetation distributions in California, the latest version of MEGAN (MEGAN v2.1) is coupled into the CLM4 (Community Land Model version 4.0) land surface scheme of WRF-Chem in this study. Multiple sensitivity experiments are conducted using this improved modeling framework at a relatively high spatial resolution to capture the region's complex topography and vegetation distribution. Simulations are conducted using WRF-Chem with a fully coupled version of CLM4 and MEGAN v2.1 (i.e., CLM4 and MEGAN share a consistent vegetation data set) and compared with the measurements collected during CARES and CalNex conducted in June 2010. This new coupling also adds the capability of quantifying the impact of different vegetation distributions on simulating BVOCs. Simulations are also performed using two land surface schemes (Noah and CLM4) coupled with MEGAN v2.0. As with previous studies using WRFChem, MEGAN v2.0 uses a different vegetation data set from the land surface schemes. The WRF-Chem experiments with MEGAN v2.0 and MEGAN v2.1 are included together here as a reference for future studies in the community and for users interested in migrating from the widely used v2.0 to v2.1.

The rest of manuscript is organized as follows. Sections 2 and 3 describe the WRF-Chem model and the observations used in this study, respectively. The sensitivity of modeling BVOCs to the land surface schemes and the vegetation distributions are analyzed in Sect. 4. The findings are then summarized and discussed in Sect. 5. 


\section{Model description and experimental design}

\subsection{WRF-Chem}

The WRF-Chem (v3.5.1) configuration is similar to that used by Fast et al. (2014) for studying aerosol evolution over California, except that this study excludes aerosols and focuses on simulated BVOCs. The model includes numerous options for the treatment of physics and chemistry processes. In this study, the SAPRC-99 (Statewide Air Pollution Research Center 1999) photochemical mechanism (Carter, 2000a, b) is selected to simulate gas-phase chemistry, and the FastJ parameterization (Wild et al., 2000) for photolysis rates. For all the simulations in this study, we use the Yonsei University (YSU) parameterization (Hong et al., 2006) for the planetary boundary layer (PBL), the Monin-Obukhov similarity theory (Paulson, 1970) to represent the surface layer, the Morrison two-moment parameterization (Morrison et al., 2009) for cloud microphysics, the Kain-Fritsch parameterization (Kain, 2004) for sub-grid scale clouds and precipitation and the rapid radiative transfer parameterization (RRTMG) for longwave and shortwave radiation (Iacono et al., 2008). Since Fast et al. (2014) has already evaluated the simulated meteorological fields and gases and aerosols with a similar model configuration, this study will focus primarily on the BVOC simulation.

\subsection{Land surface schemes}

Two land surface schemes, Noah and CLM4.0, are used to quantify how differences in the treatment of land surface processes, including latent and sensible heat fluxes, soil moisture and surface albedo, affect near-surface meteorological conditions and consequently simulated BVOC emissions and concentrations. The Noah land surface scheme, described by Barlage et al. (2010) and LeMone et al. (2010a, b), has been used in numerous studies with WRF-Chem. Noah has four soil layers, with a total depth of $2 \mathrm{~m}$ and a single slab snow layer that is lumped with the top-soil layer, which is set to a combined depth of $10 \mathrm{~cm}$. It uses the 24 United States Geological Survey (USGS) land use types, and does not treat sub-grid scale variability within a model grid cell.

The CLM4 (Community Land Model version 4.0) (Lawrence et al., 2011; Jin and Wen, 2012) was recently coupled and released with WRF (since v3.5) as one of the land surface scheme options. CLM4 in global and region applications has been shown to be accurate in describing snow, soil and vegetation processes (Zeng et al., 2002; Jin and Miller, 2007; Zhao et al., 2014). CLM4 includes 5 layers for snow, 10 layers for soil and 1 layer for vegetation. The soil is divided into 19 categories defined according to percentages of sand and clay. The two-stream approximation (Dickinson, 1983) is applied to vegetation when calculating solar radiation reflected and absorbed by the canopy as well as radiation transfer within the canopy. Each model grid cell can be divided into a maximum of 10 smaller cells to account for sub-grid scale heterogeneity and its impact on the land surface processes. The 24 USGS land use types are mapped to the 16 plant functional types (PFTs) in CLM4 based on a lookup table derived from Bonan (1996). Additional technical details of CLM4 are provided in Oleson et al. (2010).

\subsection{MEGAN and coupling with CLM4}

MEGAN is a modeling framework for estimating fluxes of biogenic compounds between terrestrial ecosystems and the atmosphere using simple mechanistic algorithms to account for the major known processes controlling biogenic emissions (Guenther et al., 2006, 2012). Two versions (v2.0 and v2.1) of MEGAN are used in this study. MEGAN v2.1 is an update from MEGAN v2.0 (Guenther et al., 2006; Sakulyanontvittaya et al., 2008) that includes additional compounds, emission types, and controlling processes. MEGAN v2.1 estimates emissions $\left(F_{i}\right)$ for 19 compound classes $(i)$ from terrestrial landscapes based on emission factors $\left(\varepsilon_{i, j}\right)$ at standard conditions for vegetation type $j$ with fractional grid box areal coverage $\chi_{j}$, i.e., $F_{i}=\gamma_{i} \Sigma \varepsilon_{i, j} \chi_{j}$, where $\gamma_{i}$ is emission activity factor from the processes controlling emission responses to environmental and phenological conditions (Guenther et al., 2006, 2012).

For emission factors, MEGAN v2.0 enabled users to customize vegetation emission type schemes ranging from detailed (e.g. individual plant species or sub species) to generic (e.g. a few broad vegetation categories). MEGAN2.1 emission factors can be specified from gridded maps based on species composition and species-specific emission factors or by using PFT distributions and the PFT specific emission factors. MEGAN2.0 defines emission factors as the net flux of a compound into the atmosphere, while MEGAN2.1 emission factor represents the net primary emission that escapes into the atmosphere but is not the net flux because it does not include the downward flux of chemicals from above canopy. The difference in the definition (net flux vs. primary emission) of emission factors affects the emission factors of compounds with bi-directional exchange but does not impact MEGAN isoprene and monoterpene emission factors because they have small deposition rates relative to emission rates. In this study, both MEGAN v2.0 and v2.1 estimate biogenic species emissions based on the PFT distributions and the PFT specific emission factors. MEGAN v2.0 and v2.1 use 4 and 16 PFTs, respectively, as described below in Sect. 2.4.

The publicly available version of WRF-Chem includes the MEGAN v2.0 scheme for calculating BVOC emission fluxes (WRF-Chem user guide: http://ruc.noaa.gov/wrf/ WG11/Users_guide.pdf). It has been widely used for gas and aerosol simulations (e.g., Shrivastava et al., 2011, 2013; Gao et al., 2011, 2014; Knote et al., 2014; Fast et al., 2014). In the released version, MEGAN v2.0 can be used with any land surface scheme available in WRF-Chem including Noah and CLM4. However, MEGAN v2.0 was originally not 
coupled into the land surface scheme in WRF-Chem (since v3.1). The biogenic emission calculation in MEGAN uses both instantaneous and the past-days' surface air temperature and solar radiation. MEGAN v2.0 obtains the instantaneous value from the land surface scheme and the pastdays' value from the climatological monthly mean data set. In contrast, MEGAN v2.1 obtains both values directly from CLM. Figure 1 shows the example of the comparison between the input climatological and model simulated monthly mean surface air temperature in June. It is apparent that the monthly averaged simulated surface air temperature is much different from the climatology value. In addition, the vegetation data set (referred to as VEG-M; will be discussed in Sect. 2.4) used in MEGAN v2.0 for calculating BVOC emission fluxes is also different from the one used by the land surface scheme, which allows MEGAN v2.0 to be used with any of the available land surface schemes (e.g., Noah and CLM4) in WRF-Chem. This inconsistency in vegetation distributions may introduce errors in simulating emissions and concentrations of BVOC. To avoid this inconsistency, we have coupled MEGAN v2.1 with WRF-Chem embedded in the CLM4 land surface scheme. Therefore, the coupling of MEGAN v2.1 and CLM4 in WRF-Chem now has the same functionality as CLM4 in the Community Earth System Model (CESM) (Lawrence et al., 2011). With this coupling strategy, MEGAN v2.1 also uses the same vegetation data set (i.e., 16 PFTs converted from the USGS data set as discussed in Sect. 2.2) that CLM4 uses for all other land surface processes; this means, however, that MEGAN v2.1 can only be used with CLM4 in WRF-Chem. In addition, MEGAN v2.1 can compute BVOC emissions that account for the sub-grid variability of vegetation distributions within CLM4.

\subsection{Vegetation data sets}

As mentioned previously, the first 16-PFT data set (referred to as USGS hereafter) used by CLM4 is converted from the default 24 USGS land cover data set used by WRF-Chem based on a lookup table derived from Bonan (1996). This method is also applied to three other 16-PFT data sets (referred to as VEG1, VEG2 and VEG3) used by CLM4 in WRF-Chem. The sensitivity of simulating BVOC emissions by CLM4 to these four 16-PFT data sets is quantified. The VEG1, VEG2 and VEG3 data sets are derived from different sources as described next.

The VEG1 data set is from the PFT fractional cover product by Ke et al. (2012), which was developed from the Moderate Resolution Imaging Spectroradiometer (MODIS) PFT classifications for the year 2005 for determining seven PFTs including needleleaf evergreen trees, needleleaf deciduous trees, broadleaf evergreen trees, broadleaf deciduous trees, shrubs, grass and crops for each $500 \mathrm{~m}$ pixel. The WorldClim 5 arcmin $\left(0.0833^{\circ}\right.$ ) (Hijmans et al., 2005) climatological global monthly surface air temperature and precipitation data were interpolated to a $500 \mathrm{~m}$ grid and used to fur-

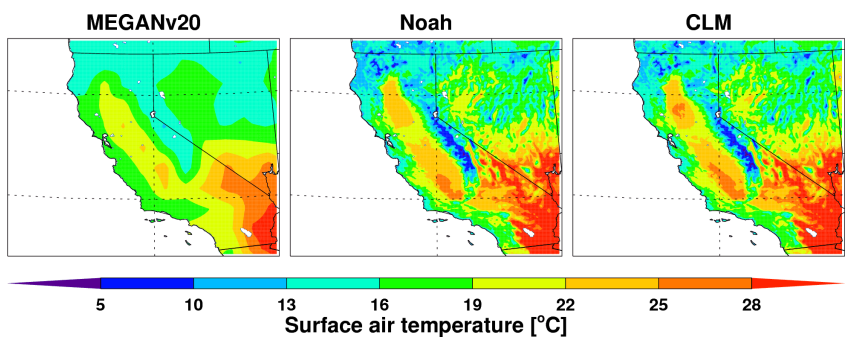

Figure 1. Spatial distributions of monthly mean surface air temperature in June 2010 from the MEGAN v2.0 climatology data set (MEANv20, prescribed) and the WRF-Chem simulations with the Noah (Noah, simulated) and CLM4 (CLM, simulated) land surface schemes.

ther reclassify the PFTs into 15 PFTs, and fractions of crop grasses were mapped based on the method presented in Still et al. (2003). Pixels with barren land and urban areas were reassigned to the bare soil class. The bare soil and the 15 PFTs from the $500 \mathrm{~m}$ grid were then aggregated to a $0.05^{\circ}$ grid.

The VEG2 data set is obtained from the NCAR (National Center for Atmospheric Research) CESM data repository (Oleson et al., 2010), available on a $0.05^{\circ}$ grid and derived using a combination of the 2001 MODIS Vegetation Continuous Field (VCF), the MODIS land cover product for year 2000 (Lawrence and Chase, 2006, 2007) and 19921993 AVHRR (Advanced Very High Resolution Radiometer) Continuous Field Tree Cover Project data (Lawrence and Chase, 2007; Lawrence et al., 2011). The monthly surface air temperature and precipitation data from Willmott and Matsuura (2001) was used to further reclassify the 7 PFTs into bare soil and 15 PFTs in the tropical, temperate and boreal climate groups based on climate rules described by Bonan et al. (2002). Fractions of crop grasses were mapped based on the method presented in Still et al. (2003).

The VEG3 data set is derived from a high-resolution ( $30 \mathrm{arcsec})$ data set over the USA with 16 PFT classifications for the year 2008. The data set was created by combining the National Land Cover Dataset (NLCD; Homer et al., 2004) and the Cropland Data Layer (see http: //nassgeodata.gmu.edu/CropScape/), both of which were based on the $30 \mathrm{~m}$ LANDSAT-TM (Land Satellite Thematic Mapper) satellite data. Vegetation species composition information was obtained from the Forest Inventory and Analysis (see http://www.fia.fs.fed.us) and the soil data from the Natural Resources Conservation Services (see http:// sdmdataaccess.nrcs.usda.gov/). The processing included adjusting the NLCD tree cover estimates in urban areas to account for the substantial underestimation of trees in the LANDSAT-TM data (Duhl et al., 2012). This was accomplished using the regionally specific adjustment factors for urban NLCD developed by Greenfield et al. (2009), using high-resolution imagery. 

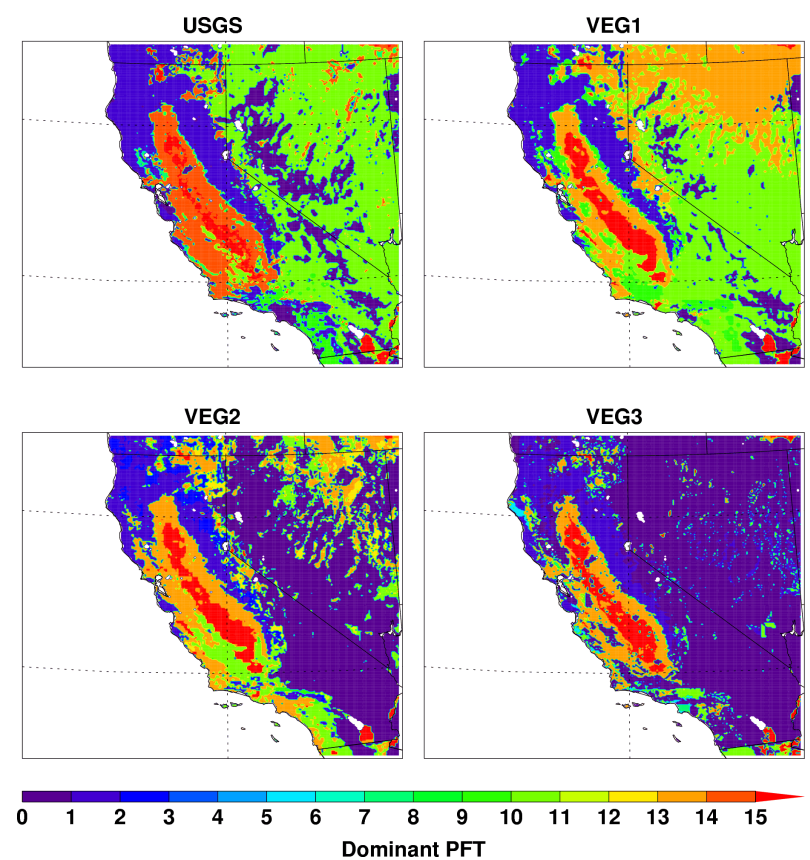

$\begin{array}{ccc}7 & 8 & 9 \\ \text { Dominant } & P F\end{array}$

Figure 2. Spatial distribution of dominant PFTs over the simulation domain from the four data sets: USGS, VEG1, VEG2, and VEG3. The PFT number refers to the list in Table 1.

Figure 2 shows the spatial distributions of the dominant PFT in each $4 \mathrm{~km} \times 4 \mathrm{~km}$ grid cell of the simulation domain from each of the four data sets. Not only are the griddominant PFTs very different among the four data sets, but also the sub-grid distributions of PFTs are different (not shown). The domain-averaged fractions of 16 PFTs from the four data sets listed in Table 1 also illustrate the differences in PFT distributions. For example, the fraction of temperate broadleaf deciduous trees ranges from $0.4 \%$ in VEG1 to $1.8 \%$ in VEG2 and the fraction of temperate broadleaf deciduous shrubs ranges from $10.8 \%$ in VEG3 to $37.5 \%$ in VEG1. In MEGAN v2.0 of WRF-Chem, only four PFTs (refer to VEG-M), i.e., broadleaf tree, needleleaf tree, shrub and herbaceous vegetation categories, are considered for the biogenic emission calculation because they are the only ones included in the MEGAN v2.0 PFT scheme. As discussed previously, these are different from the USGS vegetation distribution used by Noah and CLM4 and may cause additional biases. The distributions of the four PFTs used by MEGAN v2.0 are shown in Fig. 3. This difference in PFT distributions can affect the BVOC emission calculations primarily through determining distributions of PFT specific emission factors and LAI that are prescribed with PFTs in this study. For example, Fig. 4 shows the biogenic isoprene emission factor for each PFT prescribed in MEGAN v2.0 and MEGAN v2.1 in CLM4. In MEGAN v2.1, it shows that the temperate broadleaf deciduous tree (PFT 7 listed in Table 1) has a large isoprene emission factor, while the temperate needleleaf evergreen tree (PFT 1 listed in Ta-
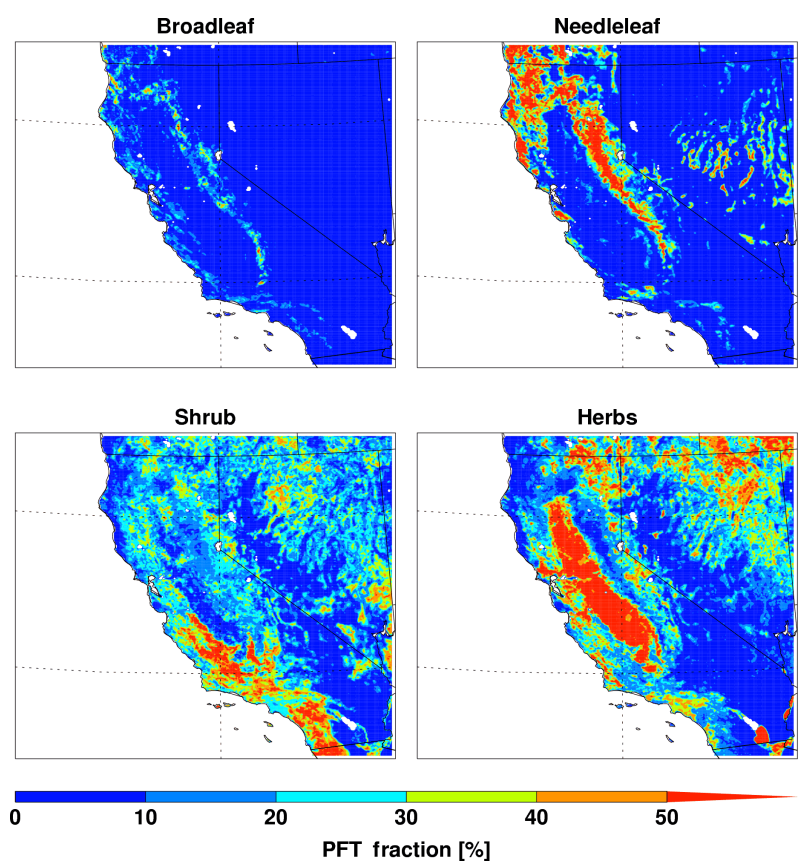

Figure 3. Spatial distribution of percentage of the four PFTs from the VEG-M used by MEGAN v2.0 over the simulation domain.

ble 1) has a small isoprene emission factor. A similar difference between broadleaf trees and needleleaf trees is indicated for MEGAN v2.0. Figure 5 shows the spatial distributions of averaged biogenic isoprene emission factor used in MEGAN v2.0 and v2.1 with different PFTs. It is evident that the difference in the distributions of PFTs results in a significant difference in spatial distributions of the isoprene emission factor. Figure 6 shows the spatial distributions of LAI used for MEGAN v2.0 and v2.1. The differences in the spatial distributions of LAI can significantly affect the biogenic emission calculation in MEGAN. It should be noted that in MEGAN v2.0 used in WRF-Chem, the LAI used for the calculation of the biogenic emissions is prescribed using the four PFTs, which is different than the land scheme that uses the LAI derived from the 24 USGS land categories.

\subsection{Numerical experiments}

The simulations are performed using a domain encompassing California (Fig. 1) with a horizontal grid spacing of $4 \mathrm{~km}$ and $279 \times 279$ grid cells $\left(113-128^{\circ} \mathrm{W}, 32-43^{\circ} \mathrm{N}\right)$ and 51 vertical layers up to $100 \mathrm{hPa}$ with about 35 layers below $2 \mathrm{~km}$. The simulation period is from 25 May to 30 June 2010, but only the results in June are used for analysis to allow for the model to spin-up realistic distributions of trace gases. The initial and boundary conditions are prescribed by large-scale meteorological fields obtained from the North American Regional Reanalysis (NARR) data with updates provided at $6 \mathrm{~h}$ intervals, which also provide the prescribed sea surface temperature (SST) for the simulations. The modeled $u$ and $v$ wind 
Table 1. Average percentage of PFTs over the simulation domain.

\begin{tabular}{llrrrr}
\hline PFT no. and description & USGS $^{\mathrm{a}}$ & VEG1 $^{\mathrm{b}}$ & VEG $^{\mathrm{c}}$ & VEG3 $^{\mathrm{d}}$ \\
\hline 0 & Bare soil & 26.0 & 7.6 & 38.1 & 41.6 \\
1 & Needleleaf evergreen tree - temperate & 13.0 & 12.5 & 9.1 & 10.7 \\
2 & Needleleaf evergreen tree - boreal & 0.0 & 0.1 & 0.0 & 4.9 \\
3 & Needleleaf deciduous tree - boreal & 0.1 & 0.0 & 0.0 & 0.0 \\
4 & Broadleaf evergreen tree - tropical & 0.0 & 0.0 & 0.0 & 0.0 \\
5 & Broadleaf evergreen tree - temperate & 0.0 & 0.4 & 1.9 & 0.0 \\
6 & Broadleaf deciduous tree - tropical & 2.9 & 0.0 & 0.0 & 0.0 \\
7 & Broadleaf deciduous tree - temperate & 1.5 & 0.4 & 1.8 & 1.5 \\
8 & Broadleaf deciduous tree - boreal & 0.0 & 0.0 & 0.0 & 0.3 \\
9 & Broadleaf evergreen shrub - temperate & 21.1 & 5.3 & 0.0 & 0.3 \\
10 & Broadleaf deciduous shrub - temperate & 20.0 & 37.5 & 27.4 & 10.8 \\
11 & Broadleaf deciduous shrub - boreal & 0.9 & 0.2 & 0.0 & 1.0 \\
12 & C 3 arctic grass & 0.0 & 0.0 & 1.2 & 2.2 \\
13 & C 3 grass & 1.0 & 28.0 & 14.9 & 18.9 \\
14 & C 4 grass & 10.4 & 0.0 & 0.0 & 0.0 \\
15 & Crop & 3.2 & 6.5 & 4.1 & 6.3 \\
\hline
\end{tabular}

${ }^{a}$ USGS is the 16-PFT data set converted from the default 24 USGS land cover data set based on a lookup table

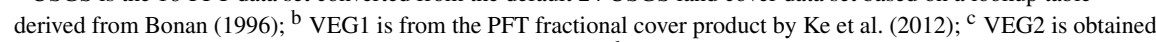
from the NCAR CESM data repository (Oleson et al., 2010); ${ }^{\mathrm{d}}$ VEG3 is derived from a data set over the USA with 16-PFT classifications by combining the National Land Cover Dataset (NLCD; Homer et al., 2004) and the Cropland Data Layer (see http://nassgeodata.gmu.edu/CropScape/).

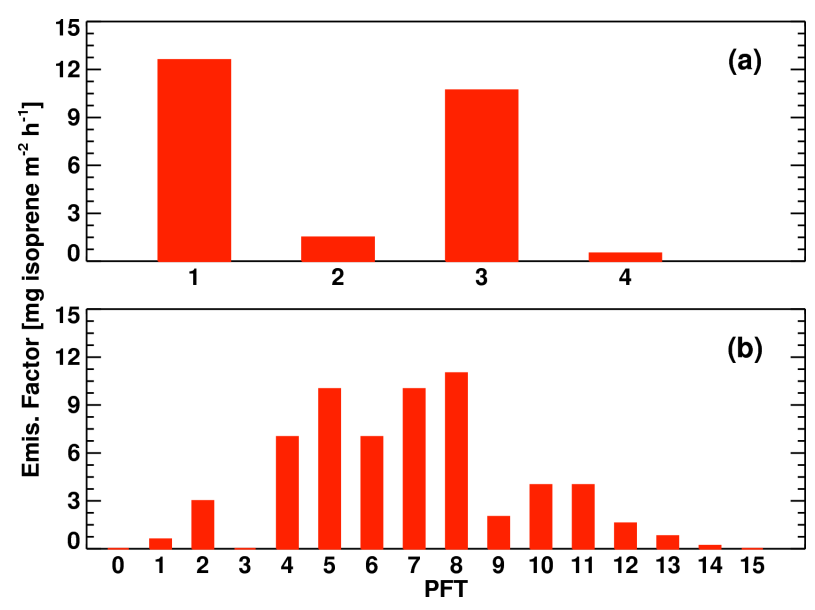

Figure 4. Biogenic isoprene emission factor for each PFT in (a) MEGAN v2.0, the PFT number 1-4 refers to broadleaf, needleleaf, shrub, and herbs, respectively; (b) MEGAN v2.1, the PFT number $0-15$ refers to the list in Table 1 .

components and temperature in the free atmosphere above the planetary boundary layer are nudged towards the NARR reanalysis data with a timescale of $6 \mathrm{~h}$ (Stauffer and Seaman, 1990). Chemical lateral boundary conditions are from the default profiles in WRF-Chem, which are based on the averages of mid-latitude aircraft profiles from several field studies over the eastern Pacific Ocean (McKeen et al., 2002).

Anthropogenic emissions were obtained from the CARB 2008 Arctic Research of the Composition of the Troposphere from Aircraft and Satellite (ARCTAS) emis-

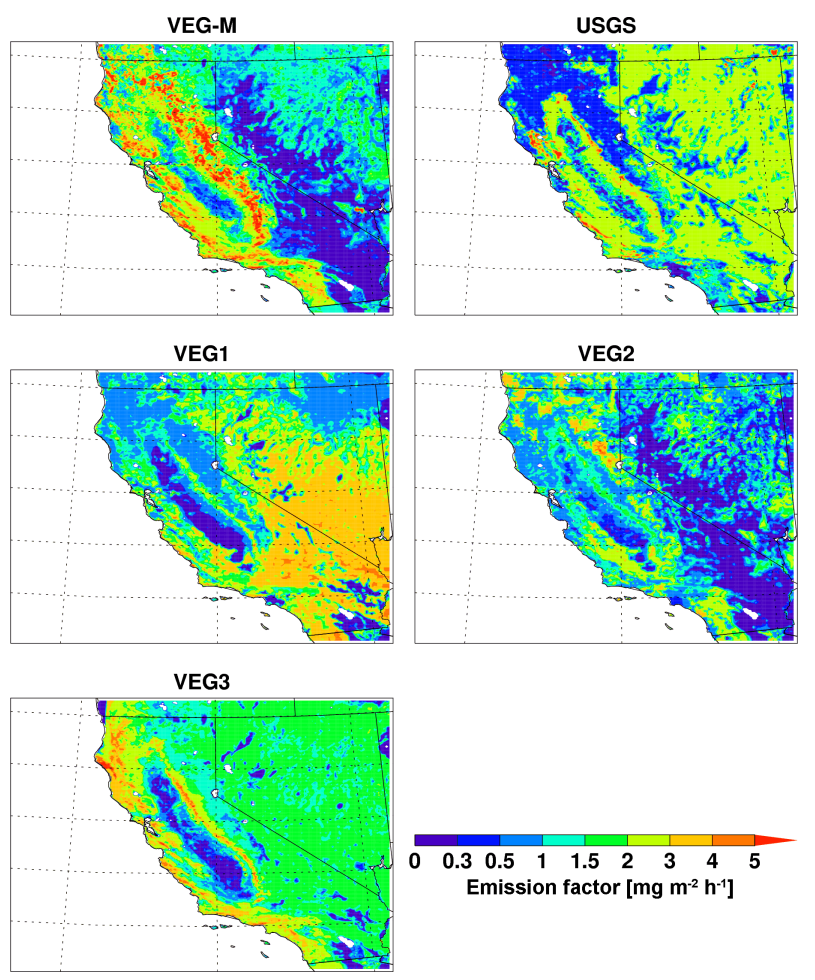

Figure 5. Spatial distribution of PFT-weighted mean biogenic isoprene emission factor derived with the VEG-M in MEGAN v2.0 and the USGS, VEG1, VEG2 and VEG3 in MEGAN v2.1. 


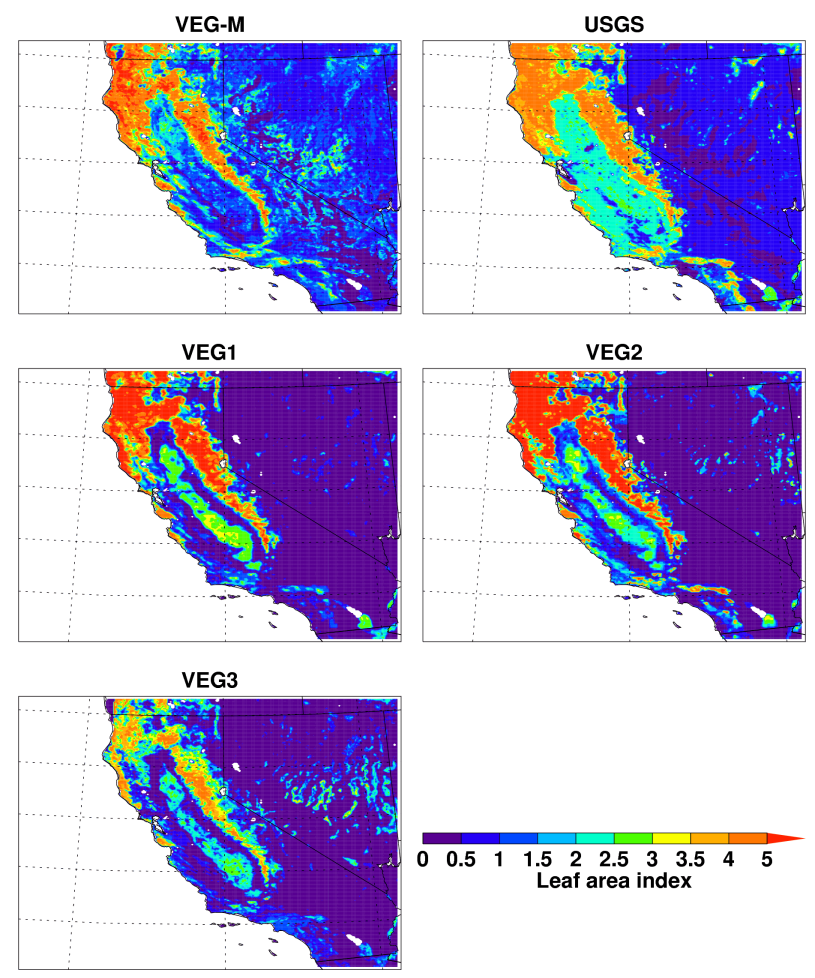

Figure 6. Spatial distribution of leaf area index (LAI) from the VEG-M in MEGAN v2.0 and from the USGS, VEG1, VEG2 and VEG3 in MEGAN v2.1.

sion inventory developed for the NASA ARCTAS mission over California (Pfister et al., 2011). The CARB inventory contains hourly emissions for a 13-day period using a $4 \mathrm{~km}$ grid spacing over California. We created diurnally averaged emissions from 5 of the weekdays and 2 of the weekend days and used those averages for all weekdays and weekends and applied these over the entire simulation period. Anthropogenic emissions from the 2005 National Emissions Inventory (NEI) (WRF-Chem user guide from http://ruc.noaa.gov/wrf/WG11/Users_guide.pdf) were used for regions outside of California. Biomass burning is not considered in the present study, because satellite detection methods indicated that there were very few fires in California during the simulation period. Biogenic emissions were computed online using the MEGAN model and lumped into isoprene, terpenes and sesquiterpenes for the SAPRC-99 photochemical mechanism.

As discussed previously, multiple numerical experiments summarized in Table 2 are conducted with different combinations of land surface schemes and vegetation data sets to investigate the sensitivity of BVOC simulation to land surface schemes and vegetation distributions. First, we conduct two experiments using MEGAN v2.0 coupled with the Noah (Mv20Noah) and CLM4 (Mv20CLM) land surface schemes. The Noah land surface scheme is only coupled with MEGAN v2.0 in WRF-Chem. In these two experiments, the two land surface schemes use the USGS vegetation distributions while MEGAN v2.0 uses a separate vegetation map (VEG-M) to estimate BVOC emissions. By comparing these two experiments, the impact of land surface schemes on simulated BVOC concentrations are examined. Second, we conduct four experiments using MEGAN v2.1 embedded in the CLM4 land surface scheme with four different vegetation data sets, i.e., USGS (Mv21USGS), VEG1 (Mv21V1), VEG2 (Mv21V2) and VEG3 (Mv21V3). The differences among these four experiments show the impact of vegetation distributions on simulated BVOC concentrations.

We note that MEGAN v2.0 and v2.1 use different vegetation data sets and are implemented in WRF-Chem in different ways, but the objective of this study is not to explore how the formulations of these two versions of MEGAN affect BVOC concentrations. The better way for exploring the version difference of MEGAN is to implement both versions in the same way and use the same vegetation data set. The simulated BVOC emissions and concentrations by WRF-Chem with MEGAN v2.0 and MEGAN v2.1 are included together here as a reference for future studies in the community and for users interested in migrating from the widely used v2.0 to v2.1.

\section{Observations}

Measurements of VOCs collected by proton transfer reaction mass spectrometer (PTR-MS) instruments (Lindinger et al., 1998) and a gas chromatography instrument (Gentner et al., 2012) over California during June of 2010 as part of the CARES and CalNex campaigns are used to evaluate the simulated isoprene and monoterpene concentrations. CARES was designed to address science issues associated with the interactions of biogenic and anthropogenic precursors on SOA, black carbon mixing state, and the effects of organic species and aerosol mixing state on optical properties and the activation of cloud condensation nuclei (Zaveri et al., 2012). As shown in Fig. 7, ground-based instruments were deployed at two sites (T0 and T1) in northern California: T0 in Sacramento $\left(38.649^{\circ} \mathrm{N},-121.349^{\circ} \mathrm{W}\right.$; $\sim 30 \mathrm{~m}$ m.s.l.; denoted by red upward triangle) and $\mathrm{T} 1$ in $\operatorname{Cool}\left(38.889^{\circ} \mathrm{N}\right.$, $-120.974^{\circ} \mathrm{W} ; \sim 450 \mathrm{~m}$ m.s.l.; denoted by red downward triangle), a small town located about $40 \mathrm{~km}$ northeast of Sacramento. The U.S. Department of Energy (DOE) Gulfstream 1 $(G-1)$ research aircraft sampled meteorological, trace gas, and aerosol quantities aloft in the vicinity of the T0 and T1 sites, denoted by black lines in Fig. 8. Zaveri et al. (2012) described the instrumentation for each of the surface sites and Shilling et al. (2013) described VOC measurements on the $G-1$. Most of the sampling during CARES occurred between 2 and 28 June, and only the aircraft sampling within $1 \mathrm{~km}$ of the surface is used to evaluate model simulations because $G-1$ sampled below $1 \mathrm{~km}$ for the majority of time. 
Table 2. Experiments of WRF-Chem.

\begin{tabular}{llllllll}
\hline & Surface & BVOC & \multicolumn{5}{c}{ Plant function type data set } \\
\cline { 4 - 8 } & scheme & scheme & USGS/VEG-M & USGS & VEG1 & VEG2 & VEG3 \\
\hline \multirow{2}{*}{ WRF-Chem } & CLM4.0 & MEGANv2.0 & Mv20CLM & - & - & - & - \\
& & MEGANv2.1 & - & Mv21USGS & Mv21V1 & Mv21V2 & Mv21V3 \\
\cline { 2 - 8 } & \multirow{2}{*}{ Noah } & MEGANv2.0 & Mv20Noah & - & - & - & - \\
\hline
\end{tabular}

CalNex was designed to address science issues relevant to emission inventories, dispersion of trace gases and aerosols, atmospheric chemistry and the interactions of aerosols, clouds and radiation (Ryerson et al., 2013). Ground-based instruments were deployed at two sites in southern California as shown in Fig. 7: one in Pasadena $\left(34.141^{\circ} \mathrm{N},-118.112^{\circ} \mathrm{W} ; \sim 240 \mathrm{~mm} . \mathrm{s} .1\right.$; d denoted by the red circle) and one in Bakersfield $\left(35.346^{\circ} \mathrm{N},-118.965^{\circ} \mathrm{W}\right.$; $\sim 123 \mathrm{~m}$ m.s.l.; denoted by the red square). The NOAA (National Oceanic and Atmospheric Administration) WP-3D research aircraft sampled meteorological, trace gas and aerosol quantities aloft along flight paths shown in Fig. 7 (denoted by blue lines). While most of the CalNex aircraft tracks below an altitude of $1 \mathrm{~km}$ were conducted in southern California in the vicinity of the Los Angeles basin, the WP-3D also flew within the Central Valley and in the vicinity of Sacramento on some days. A detailed description of the instrumentation for each of the CalNex surface sites and mobile platforms is given by Ryerson et al. (2013). Most of the sampling during CalNex was conducted before 16 June and only the aircraft sampling below $1 \mathrm{~km}$ is used to evaluate the model simulations.

\section{Results}

\subsection{Impact of land surface schemes}

\subsubsection{Biogenic isoprene and monoterpene emissions}

Figure 7 shows the spatial distributions of biogenic isoprene emissions averaged over June for the six simulations listed in Table 2. Biogenic isoprene emissions occur in vegetated regions of California with the highest emission rates along the foothills of the Sierra Nevada where oak trees are the dominant plant species. To show the difference in biogenic isoprene emissions among the cases more clearly, Fig. 8a and $\mathrm{b}$ zoom in on the CARES (northern California) and CalNex (southern California) sampling regions, respectively. In both regions the differences in land surface schemes had a relatively small impact on the biogenic isoprene emissions over California in terms of both spatial distribution and magnitude, although the emissions from Mv20CLM were a little larger than those from Mv20Noah. The domain summed biogenic isoprene emissions for the entire month

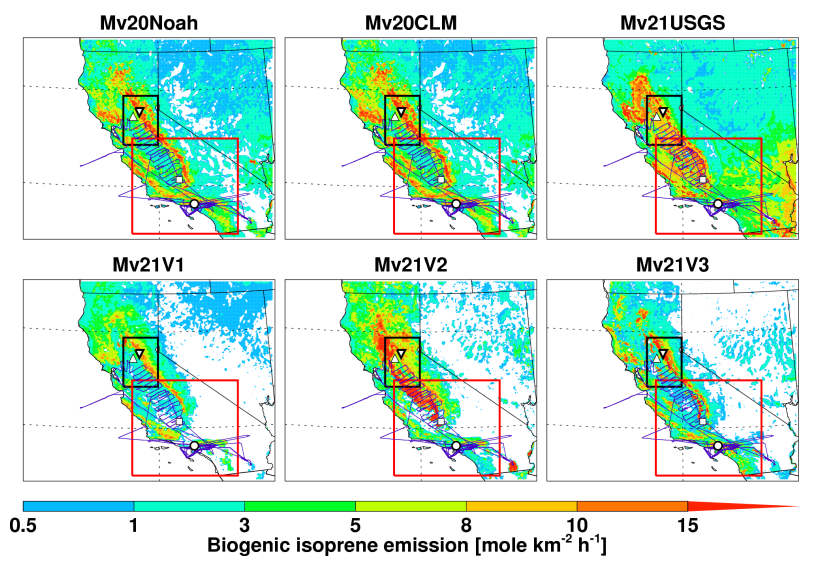

Figure 7. Spatial distributions of biogenic isoprene emissions averaged in June estimated in the six simulations as listed in Table 2. The four observation sites are shown as T0 (white upward triangle), T1 (white downward triangle), Bakersfield (white square) and Pasadena (white circle). The CalNex WP-3D flight tracks below $1 \mathrm{~km}$ (blue line) during June 2010 are also shown. The black and red boxes denote the predominant CARES and CalNex regions, respectively.

of June from Mv20Noah and Mv20CLM are $1.4 \times 10^{9}$ and $1.6 \times 10^{9}$ mole, respectively. Figure $9 \mathrm{a}$ and $\mathrm{b}$ are similar to Fig. $8 \mathrm{a}$ and $\mathrm{b}$, except that biogenic monoterpene emission fluxes are shown. In general, the spatial patterns of emissions of the two biogenic species are similar, except that the peak areas of monoterpene emissions are shifted slightly. For example, the peak monoterpene emissions in northern California occur further northeast at higher elevations of the Sierra Nevada that are dominated by needleleaf evergreen trees. The impact of land surface schemes on biogenic monoterpene emissions is also small over California in terms of both spatial patterns and magnitudes, although the emissions from Mv20CLM are a little larger than those from Mv20Noah. The domain summed biogenic monoterpene emissions for the entire month of June from Mv20Noah and Mv20CLM are $1.0 \times 10^{8}$ and $1.1 \times 10^{8}$ mole, respectively.

The similarity in estimating biogenic emissions between the experiments with two land surface schemes is also summarized in Figs. 10 and 11, which show the average diurnal biogenic isoprene and monoterpene emission rates at the four observation sites. The similarity between Mv20Noah 

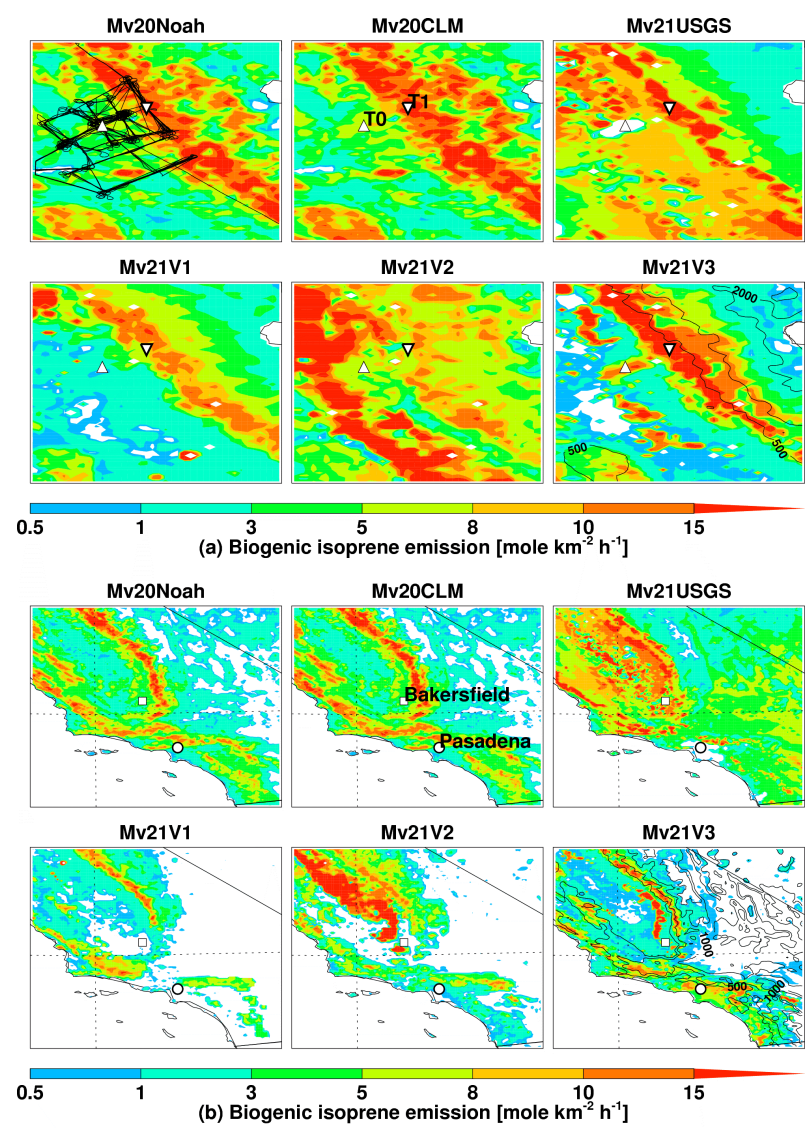

Figure 8. (a) Spatial distributions of biogenic isoprene emissions around the CARES observational sites T0 and T1 (the black box shown in Fig. 7) estimated in the six simulations as listed in Table 1. The CARES $G-1$ flight tracks below $1 \mathrm{~km}$ (black line) during June 2010 are also shown with the Mv20Noah result; the terrain height is also shown as the black contour lines with the Mv21V3 result. (b) Same as panel (a) except around the CalNex observational sites Bakersfield and Pasadena (the red box shown in Fig. 7).

and Mv20CLM (red and orange lines) is likely due to the same vegetation map in MEGAN v2.0 to estimate biogenic emissions. Although the two land surface schemes produce slightly different values of surface temperature (Fig. 1), soil moisture (not shown) and net solar radiation near the surface (not shown), their impact on the biogenic emissions was small. Both BVOC species have peak emission rates in the early afternoon. One noteworthy difference in diurnal variation of the two biogenic species emission rates is that there is no isoprene emitted during the night while the amount of monoterpenes emitted during the night is small but not negligible. This can contribute to differences in the diurnal variation of the mixing ratios of two biogenic species, as will be discussed next.
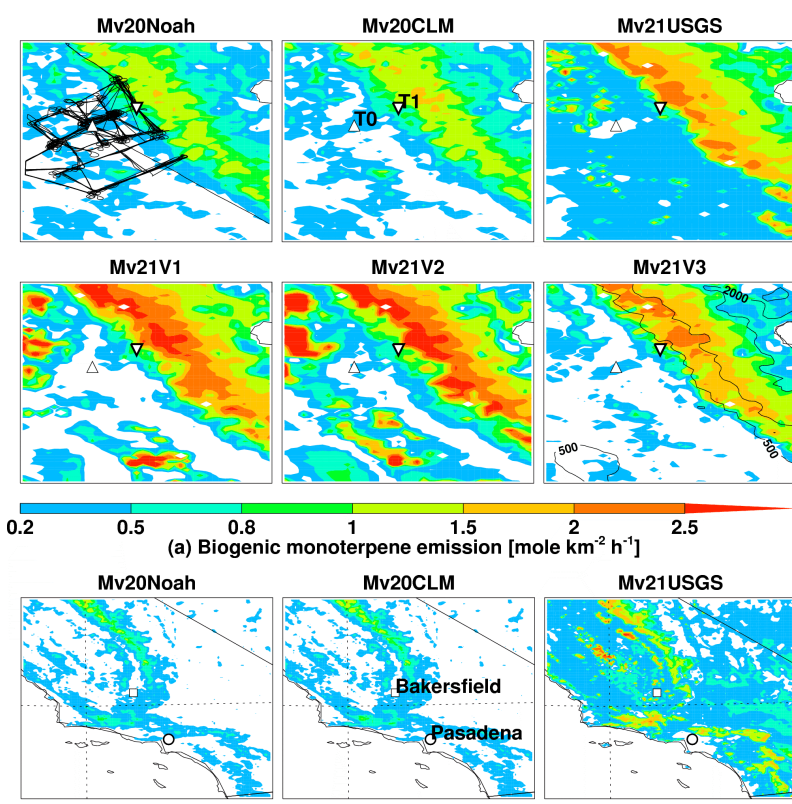

Mv20CLM

Mv21USGS

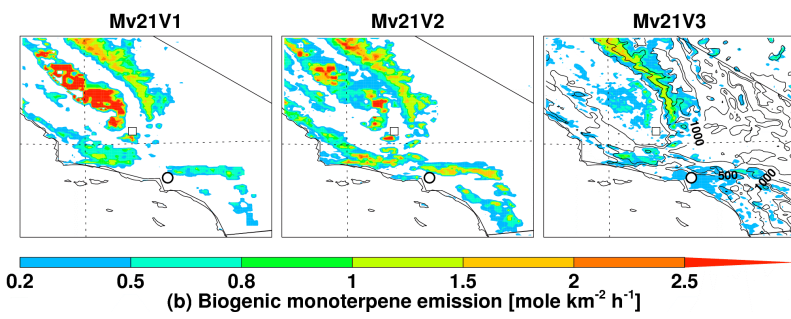

Figure 9. Same as Fig. 8, except for biogenic monoterpene emissions.

\subsubsection{Isoprene and monoterpene mixing ratios}

Figures $12 \mathrm{a}$ and $\mathrm{b}$ and $13 \mathrm{a}$ and $\mathrm{b}$ show the spatial distributions of monthly averaged surface mixing ratios of isoprene + MVK(methyl-vinylketone) + MACR(methacrolein) and monoterpenes, respectively, around the CARES (northern California) and the CalNex (central and southern California) sampling regions simulated by the six experiments listed in Table 2. Due to the fast chemical transition from isoprene to MVK and MACR, the sum of isoprene + MVK + MACR mixing ratios can better reflect the impact of biogenic isoprene emissions than isoprene mixing ratio alone (Shilling et al., 2013). In general, the spatial patterns and magnitudes of surface isoprene + MVK + MACR and monoterpene mixing ratios over the two regions are similar to the two MEGAN v2.0 experiments with the Noah and CLM4 land surface schemes. The spatial patterns of surface mixing ratios of isoprene $+\mathrm{MVK}+\mathrm{MACR}$ and monoterpenes are similar to the spatial variability in the emission rates.

There is a difference between the two experiments at specific locations, which is partly reflected in the comparison of average diurnal variations of surface mixing ratios of isoprene + MVK + MACR and monoterpenes at the four obser- 

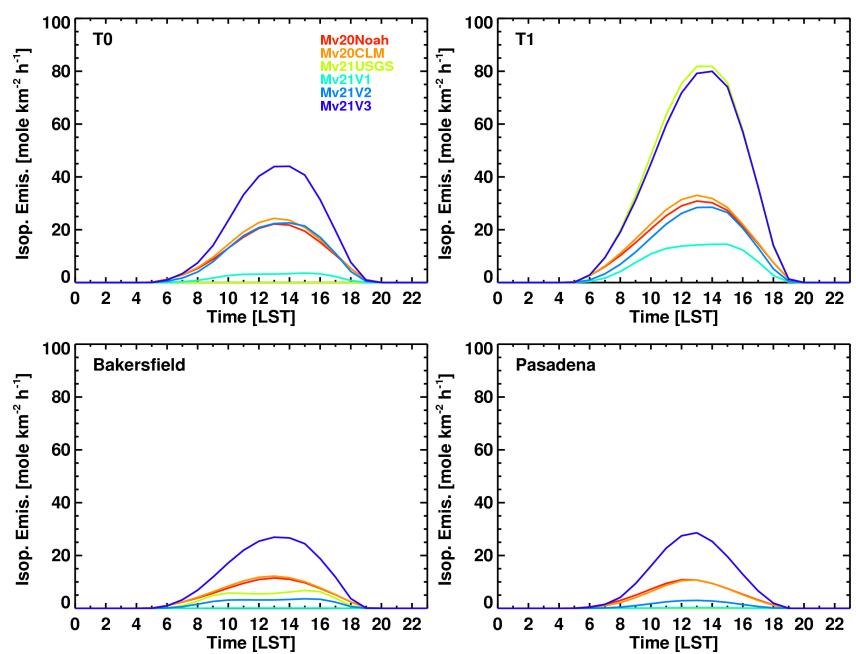

Figure 10. Average diurnal variation of biogenic isoprene emissions at the four observation sites from the six simulations listed in Table 1 .
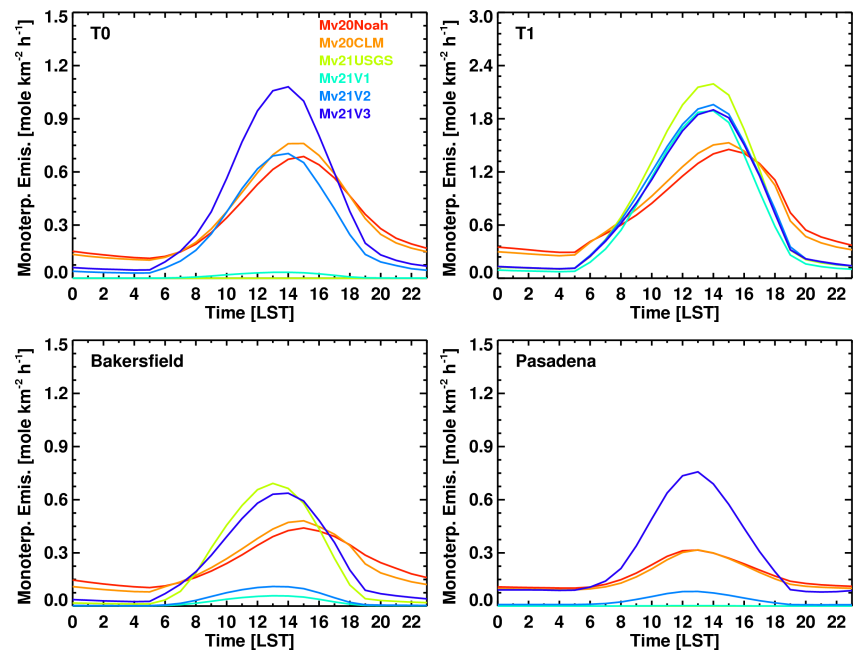

Figure 11. Same as Fig. 10, except for biogenic monoterpene emissions.

vation sites shown in Figs. 14 and 15. At the Bakersfield site, only isoprene mixing ratios were reported so that the comparison is for isoprene only. Note that the values for the Bakersfield and Pasadena sites are averaged over the first 2 weeks of June to be consistent with the observations. Although both experiments with Noah and CLM4 (red and orange lines, respectively) simulate similar isoprene emission fluxes with the maximum in the afternoon (Fig. 10), their respective isoprene $+\mathrm{MVK}+\mathrm{MACR}$ mixing ratios are different at the four sites, particularly at site T0, where the Mv20CLM simulated isoprene + MVK + MACR mixing ratios during the daytime are about a factor of 2 larger than those from Mv20Noah. This inconsistence mainly results from the differences in the near-surface meteorology, such as net surface

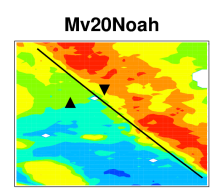

Mv20CLM

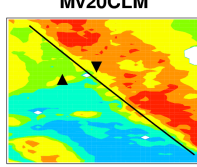

Mv21USGS

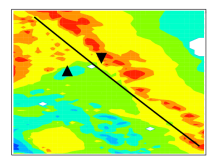

Mv21V1

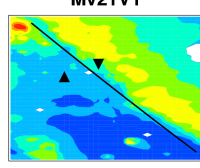

Mv21V2

Mv21V3

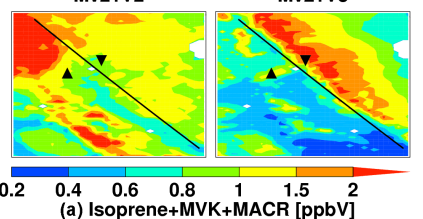

(a) Isoprene+MVK+MACR [ppbV]

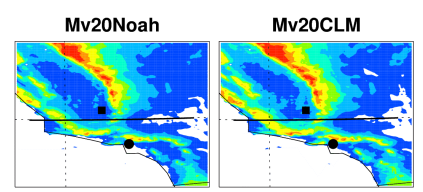

Mv21V1

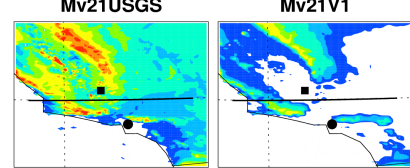

Mv21V2

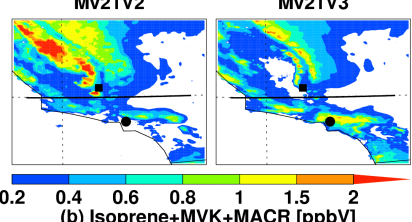

(b) Isoprene+MVK+MACR [ppbV]

Figure 12. (a) Spatial distributions of monthly averaged surface isoprene mixing ratios around the CARES T0 and $\mathrm{T} 1$ observational sites from the six simulations as listed in Table 1. The black lines parallel to the Sierra Nevada divide the region to the southwest and the northeast for comparison with CARES $G-1$ aircraft measurements shown in Figs. 16 and 17. (b) Same as panel (a) except around the CalNex observational sites Bakersfield and Pasadena. The black lines divide the region to southern California and the Central Valley for comparison with CalNex WP-3D aircraft measurements shown in Figs. 16 and 17.

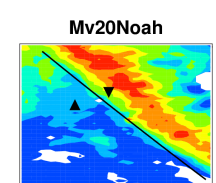

Mv21USGS

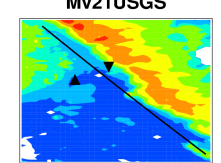

Mv21V2

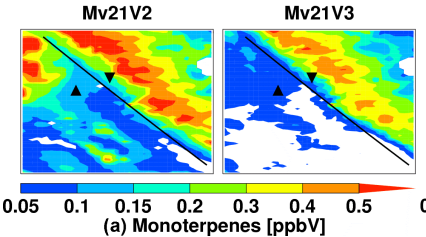

Mv20CLM

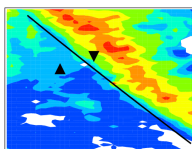

Mv21V1

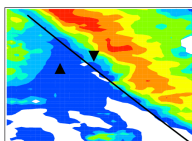

Mv21V3

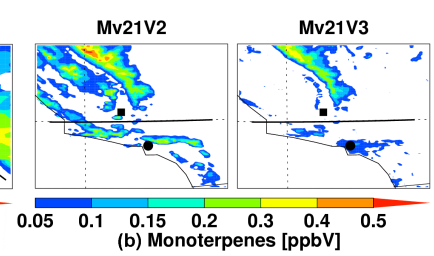

Figure 13. Same as Fig. 12, except for monoterpene.

radiation and temperature, between the two experiments (not shown) that affects photochemistry, but this impact of surface meteorology occurs only at limited locations. When compared to the observations, both experiments significantly underestimate the isoprene + MVK + MACR mixing ratios except at the Bakersfield site. Figure 15 is identical to Fig. 14, except for surface monoterpene mixing ratios. Note that there were no monoterpene data reported for the Bakersfield and Pasadena sites, so only the simulation results are shown. In contrast to isoprene + MVK + MACR, monoterpenes ex- 

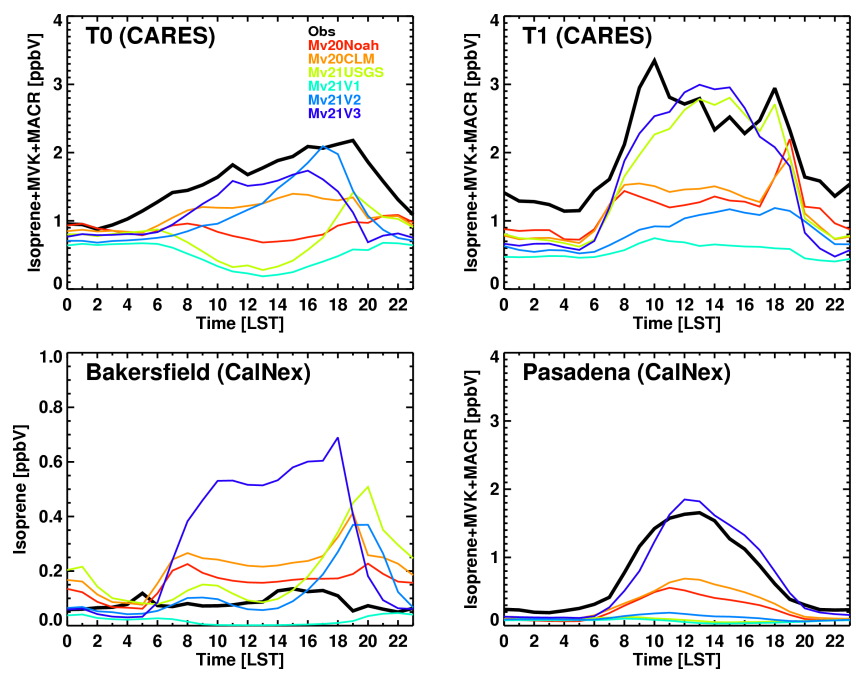

Figure 14. Monthly averaged diurnal variation of surface isoprene + MVK + MACR mixing ratios at the three observation sites and isoprene mixing ratios at the Bakersfield site from the observations and six simulations listed in Table 2 . The simulated values for the Bakersfield and Pasadena sites are averaged for the first two weeks of June to be consistent with the observations.
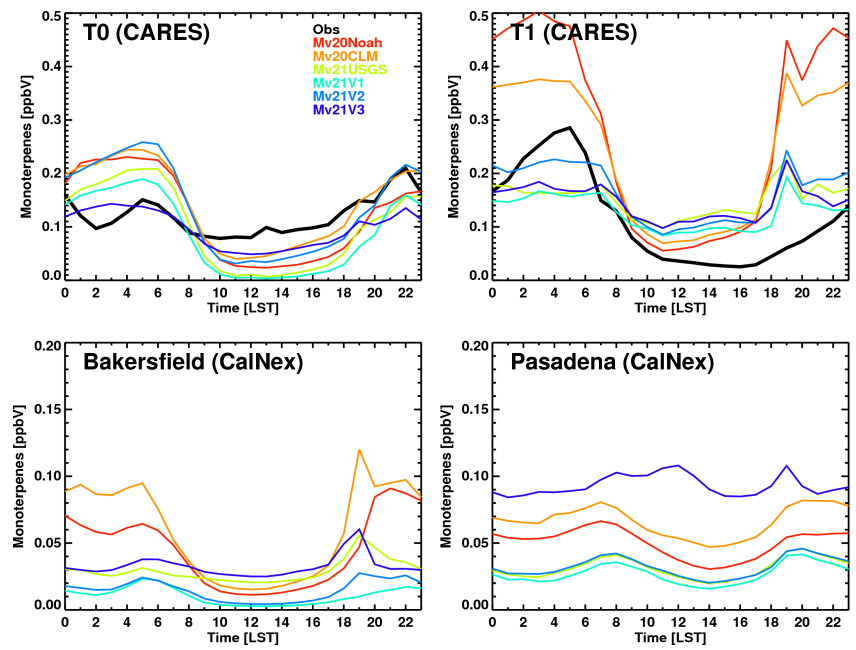

Figure 15. Monthly averaged diurnal variation of surface monoterpene mixing ratios at the four observation sites from the observations and six simulations as listed in Table 2. There are no observations for the Bakersfield and Pasadena sites in June.

hibit peak surface mixing ratios during the nighttime due to the strong photolysis activity that makes the lifetime of monoterpenes short during the daytime and the small emissions into a shallow boundary layer during the nighttime (Fig. 11). In general, the difference between the Mv20Noah and Mv20CLM experiments in monoterpene mixing ratios is relatively small at these four sites, particularly during the daytime. When compared to the observations, both experiments overestimate the diurnal variation and the nighttime surface monoterpene mixing ratios at the $\mathrm{T} 0$ and $\mathrm{T} 1$ sites.
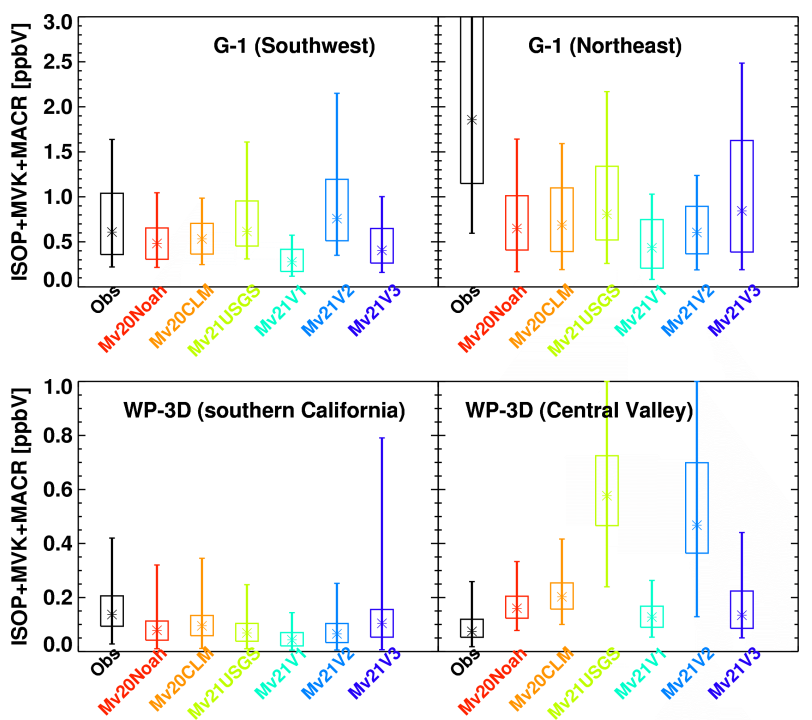

Figure 16. Comparison of isoprene $+\mathrm{MVK}+\mathrm{MACR}$ mixing ratios averaged below $1 \mathrm{~km}$ from the observations by $G-1$ flights over the southwest and northeast regions (as marked in Fig. 12a) and WP-3D flights over southern California and the Central Valley (as marked in Fig. 12b) and the corresponding simulations. Asterisk denotes the 50th percentiles. Vertical lines denote 10th and 90th percentiles and the boxes denote the 25 th and 75 th percentiles.
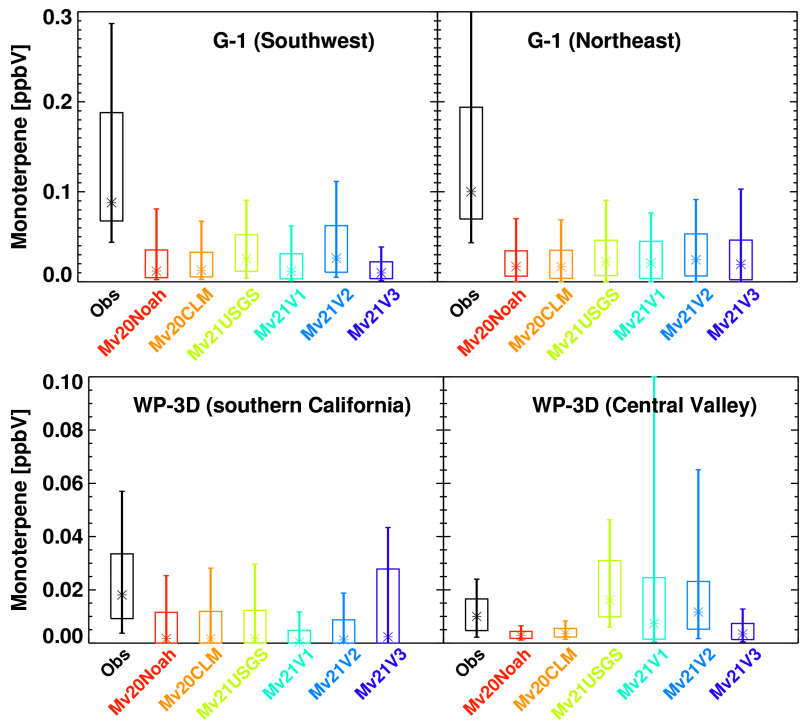

Figure 17. Same as Fig. 16 except for monoterpene mixing ratios.

Figures 16 and 17 show the comparison of the observed and simulated mixing ratios of isoprene + MVK + MACR and monoterpenes, respectively, along the $G-1$ and WP-3D flight tracks below $1 \mathrm{~km}$. Model results are sampled along the flight tracks. As shown in Fig. 7, the $G-1$ flight mainly flew over northern California around the T0 and T1 sites, while the WP-3D flew over a larger area covering both southern California and the Central Valley. To better reflect the 
spatial variability in the BVOCs, the flight tracks of both flights are separated into two regions as indicated by the black lines in Figs. 12a and b and 13a and b. For the $G-1$, the flight paths are divided into regions of southwest and northeast of the black line shown in Figs. 12a and 13a that is parallel to the Sierra Nevada. The two regions have significantly different vegetation (Fig. 2) resulting in large differences in biogenic emissions. For the WP-3D, the flight paths are divided into regions of south and north of the black line shown in Figs. 12b and 13b to separate southern California and the Central Valley. Over southern California, the measured isoprene + MVK + MACR mixing ratios by the PTRMS over the WP-3D are the upper limit since the PTR-MS may have a small interference in urban areas for isoprene and MVK + MACR.

In Fig. 16, it is interesting to note that both experiments Mv20Noah and Mv20CLM reasonably capture the variability seen in the $G-1$ isoprene + MVK + MACR measurements over the southwest region even though they underestimate the surface observations by as much as a factor of 2 at the T0 site (Fig. 14). While both experiment mixing ratios are slightly smaller than observed, the Mv20CLM simulated mixing ratios are a little larger than those from Mv20Noah and closer to the observations. Over the northeastern region, both experiments produced similar mixing ratios that were significantly smaller than the observations, which is consistent with the comparison between the simulated and observed isoprene + MVK + MACR at the T1 site (Fig. 14). As shown in Fig. 16, the Mv20CLM simulation produced somewhat larger isoprene + MVK + MACR mixing ratios than Mv20Noah in both southern California and the Central Valley. This is consistent with the comparison at the Bakersfield and Pasadena surface sites. Both simulations also underestimate and overestimate the isoprene + MVK + MACR mixing ratios over southern California and the Central Valley, respectively. The comparison of isoprene + MVK + MACR with aircraft observations may suggest that both experiments underestimate biogenic isoprene emissions over the forested foothills of Sierra Nevada and southern California around Los Angeles, but overestimate the emissions over the Central Valley. The model biases may also be affected, to some extent, by anthropogenic emissions with large uncertainties and the associated nonlinear chemistry due to the mixing of anthropogenic and biogenic plumes (Fast et al., 2014).

Figure 17 shows that both experiments Mv20Noah and Mv20CLM significantly underestimate the monoterpene mixing ratios over all the regions sampled by the $G-1$ and WP-3D aircraft and that the differences between the simulations were negligible. The average monoterpene mixing ratios sampled by the $G-1$ below $1 \mathrm{~km}$ was comparable to the surface measurement at the T0 site during the daytime, but somewhat higher than the observations at the T1 site. The simulated mixing ratios averaged along the flight tracks were much smaller than those at the two surface sites, suggesting that it may be difficult for model to simulate the large spatial heterogeneity of the monoterpene mixing ratios. This could result from the biases in biogenic monoterpene emissions and/or the chemical mechanism for monoterpene oxidation and how chemistry is coupled with turbulent mixing within the simulated convective boundary layer. It also needs to be noted that the $G-1$ and WP-3D measured monoterpene mixing ratios are generally below the limit of detection (LOD) of instruments (0.1-0.3 ppbv). Therefore, the true monoterpene mixing ratios could be of a range of between 0 to $\sim 0.1-$ $0.3 \mathrm{ppbv}$, which may also contribute to the discrepancy between observations and simulations.

\subsection{Impact of vegetation distributions}

\subsubsection{Biogenic isoprene and monoterpene emissions}

Figures $8 \mathrm{a}$ and $\mathrm{b}$ and $9 \mathrm{a}$ and $\mathrm{b}$ show that the differences in biogenic isoprene and monoterpene emission distributions due to using the various vegetation data sets are larger than the differences resulting from the two land surface schemes. The domain summed biogenic isoprene emissions for the entire month of June are 2.3, 0.76, 1.7 and $0.92\left(\times 10^{9}\right.$ mole $)$ from the experiments of Mv21USGS, Mv21V1, Mv21V2 and Mv21V3, respectively, and biogenic monoterpene emissions are 2.5, 1.7, 1.9 and $1.1\left(\times 10^{8}\right.$ mole $)$ from the four experiments. Each of the four simulations produces high biogenic isoprene and monoterpene emission rates along the Sierra Nevada that is covered mainly by oak and pine forests. However, the different forest classifications and their coverage (Table 1) produce different biogenic isoprene and monoterpene emission rates along the Sierra Nevada. Another distinct difference among these four simulations is found over the Central Valley, where the Mv21V1 and Mv21V3 experiments produce significantly lower biogenic isoprene and monoterpene emissions than the Mv21USGS and Mv21V2 experiments. This results from their different spatial distributions of vegetation types. For example, the vegetation data set in Mv21USGS assigns a relatively larger fraction of vegetation over the Central Valley to broadleaf trees, which are biggest contributors of isoprene emissions (Fig. 4).

The differences in the spatial distributions of biogenic isoprene and monoterpene emissions due to various vegetation distributions is also illustrated by the average diurnal biogenic isoprene emission rates at the four observation sites shown in Figs. 10 and 11. For example, the Mv21V3 simulation produces the largest biogenic isoprene and monoterpene emissions at three of the sites. At the $\mathrm{T} 1$ site over the forested foothills of the Sierra Nevada, the Mv21USGS and Mv21V3 simulations produce much larger biogenic isoprene emissions than Mv21V1 and Mv21V2. Even though forest is the dominant vegetation type along the foothills of the Sierra Nevada in all four vegetation data sets (Fig. 2), their different forest classifications and coverage result in biogenic isoprene emission rates that differ by as much as a factor of 8 
at the T1 site. Similar to isoprene emissions, the Mv21USGS simulation produces the largest monoterpene emissions at the $\mathrm{T} 1$ site. However, the differences in monoterpene emissions among the four vegetation data set experiments are smaller overall than that for biogenic isoprene emissions. Different vegetation distributions for a typical urban area can also lead to differences in biogenic isoprene and monoterpene emissions. For example at the urban T0 and Pasadena sites, biogenic isoprene and monoterpene emission rates are almost 0 in the Mv21USGS and Mv21V1 experiments, while the rates were significant larger in the Mv21V3 experiment. This could have profound implications on local oxidant chemistry influencing urban air quality.

\subsubsection{Isoprene + MVK + MACR and monoterpene mixing ratios}

As expected, the differences in biogenic isoprene and monoterpene emissions among the four different vegetation distribution experiments lead to large differences in the simulated surface isoprene + MVK + MACR and monoterpene mixing ratios (Figs. 12a, b and 13a, b). Although all the four experiments simulate the highest biogenic isoprene + MVK + MACR and monoterpene mixing ratios along the forested foothills of Sierra Nevada, the Mv21V1 and Mv21V3 experiments have the lowest isoprene + MVK + MACR and monoterpene mixing ratios, respectively, corresponding to their lowest biogenic emission rates. Over the Central Valley, Mv21USGS and Mv21V2 experiments produce significantly higher isoprene + MVK + MACR mixing ratios than the other two experiments, while Mv21V3 simulates the lowest monoterpene mixing ratios among all the experiments.

At the T1 site located in the forested foothills of Sierra Nevada, the Mv21V1 simulation produces the lowest isoprene + MVK + MACR mixing ratios (Fig. 14), significantly underestimating the peak concentrations during the day. In contrast, the Mv21USGS and Mv21V3 simulations reasonably capture the observed isoprene + MVK + MACR mixing ratios during the daytime. All four experiments underestimate the isoprene + MVK + MACR mixing ratios by about a factor of 2 during the night. This may indicate that the transported isoprene + MVK + MACR from the surrounding areas of $\mathrm{T} 1$ was too low. The negative biases of simulated isoprene + MVK + MACR mixing ratios over the areas surrounding $\mathrm{T} 1$ can be reflected by Fig. 16 that shows all the four experiments significantly underestimate the observed isoprene + MVK + MACR mixing ratios below $1 \mathrm{~km}$ in the northeast area around the T1 site (Fig. 12a). Figure 16 also shows that Mv21USGS and Mv21V3 simulate larger isoprene + MVK + MACR mixing ratios averaged over the northeast region of northern California than Mv21V1 and Mv21V2. All four experiments produce similar surface monoterpene mixing ratios, which are smaller than that from the Mv20Noah and Mv20CLM with MEGAN v2.0 and are closer to the observed values particularly during the night. This is consistent with their much lower biogenic monoterpene emissions during the night (Fig. 11). The four experiments with MEGAN v2.1 simulate higher daytime monoterpene mixing ratios averaged along the flight tracks below $1 \mathrm{~km}$ than the two experiments with MEGAN v2.0. The simulated mixing ratios are still much lower than the aircraft observations, although the simulated surface mixing ratios are higher than the observations at the T1 site (Fig. 15). However, the aircraft measured monoterpene mixing ratios may also be higher than the true values due to the LOD of instruments (0.1-0.3 ppbv).

At the T0 site, an urban site, the vegetation coverage in both the Mv21USGS and Mv21V1 experiments is small so that the isoprene $+\mathrm{MVK}+\mathrm{MACR}$ and monoterpene mixing ratios are significantly lower than observed during the daytime. The Mv21V2 and Mv21V3 experiments reasonably simulate isoprene + MVK + MACR mixing ratios during the daytime. Over the area surrounding the T0 site (i.e., the southwest area in Fig. 12a), it is interesting to note that the Mv21USGS and Mv21V2 simulations produced larger isoprene + MVK + MACR mixing ratios than Mv21V1 and Mv21V3 and closer to the observations (Fig. 16). This is mainly due to the relatively large isoprene + MVK + MACR mixing ratios over the northwest corner of CARES sampling region (Fig. 12a) in the Mv21USGS and Mv21V2 simulations, consistent with the distributions of biogenic isoprene emissions over the region. The Mv21V2 and Mv21V3 simulations produced higher monoterpene mixing ratios than Mv21USGS and Mv21V1, but are still smaller than the observed values during the daytime not only for the T0 site but also for the region surrounding T0 as shown in Fig. 17.

At the Bakersfield site, the experiments often simulate significantly larger isoprene mixing ratios than the observations, except for the Mv21V1 simulation that was always too small. The Mv21V3 simulation produced the highest isoprene mixing ratios among the experiments. This is consistent with its biogenic isoprene emission rates (Fig. 10). In addition, the observed surface isoprene mixing ratios show negligible diurnal variation in contrast to the experiments that produced larger diurnal variations. The Mv21V3 simulation produced peak isoprene mixing ratios during the daytime that were likely controlled by its large daytime local biogenic isoprene emission rates (Fig. 10). The Mv21USGS and Mv21V2 simulations produced peak isoprene mixing ratios during the early evening, possibly the result of chemistry and transport from regions with higher biogenic emissions. All four experiments produce small diurnal variation of surface monoterpene mixing ratios. The Mv21USGS and Mv21V3 simulations produce larger monoterpene mixing ratios than the other two, consistent with their local emission rates (Fig. 11).

At the Pasadena site, the Mv21V3 simulation reproduces the observed diurnal variation of isoprene $+\mathrm{MVK}+\mathrm{MACR}$ mixing ratios reasonably well. This is consistent with the area surrounding the Pasadena site, in which the 
Mv21V3 simulation produces the largest mixing ratios of isoprene + MVK + MACR both at the surface (Fig. 12b) and aloft (Fig. 16) in the vicinity of Los Angeles. The other three experiments simulated significantly smaller mixing ratios of isoprene + MVK + MACR. Although the values from the other three experiments are still smaller than the observations, they are much closer to the aircraft measurements (within a factor of 2) than at the Pasadena site (Fig. 14). Among the four vegetation sensitivity simulations, Mv21V3 produces higher surface monoterpene mixing ratios than the other three experiments, consistent with their emission rates (Fig. 11). All four vegetation sensitivity experiments produced much lower monoterpene mixing ratios below $1 \mathrm{~km}$ (Fig. 17), compared to the aircraft measurements over southern California that may overestimate the true values due to the LOD of instruments ( $0.1-0.3 \mathrm{ppbv})$.

As discussed previously, all four experiments simulate significantly different isoprene + MVK + MACR and monoterpene mixing ratios over the Central Valley (Figs. 12a, b and 13a, b). The Mv21USGS and Mv21V2 simulations produce much larger isoprene + MVK + MACR mixing ratios (0.6 and $0.5 \mathrm{ppbV}$, respectively) over the Central Valley than the observed values $(\sim 0.1 \mathrm{ppbV})$. The Mv21V1 and Mv21V3 simulations produce monoterpene mixing ratios much closer to observed values. This may indicate that the fraction of broadleaf trees (the main emitter over the region) over the Central Valley from the vegetation data sets USGS and VEG2 are overestimated or the biogenic emission factors estimated for the broadleaf trees are overestimated for this area. For monoterpenes, the Mv21V3 simulation was much smaller than observed, while the mixing ratios from the other three experiments were more comparable. This suggests that the fraction of vegetation emitting monoterpenes is significantly underestimated over this area in the VEG3 data set.

\section{Summary and discussion}

In this study, the latest version of MEGAN (v2.1) is coupled within the CLM4 land scheme as part of WRF-Chem. Specifically, MEGAN v2.1 is implemented into the CLM4 scheme so that a consistent vegetation map can be used for estimating biogenic VOC emissions as well as surface fluxes. This is unlike the older version of MEGAN (v2.0) in the public-released WRF-Chem that uses a stand-alone vegetation map that differs from what is used in land surface schemes. With this improved WRF-Chem modeling framework coupled with CLM4-MEGAN v2.1, the sensitivity of biogenic VOC emissions and hence of atmospheric VOC mixing ratios to vegetation distributions is investigated. The WRF-Chem simulations are also conducted with the two land surface schemes, Noah and CLM4, with the MEGAN v2.0 scheme for biogenic emissions in each case. The comparison between the Noah- and CLM4-driven MEGAN v2.0 biogenic emissions not only serves for investigating the impact of different land surface schemes on the emissions but also provides a reference for all previous studies that used the Noah land surface scheme. Experiments are conducted for June 2010 over California, compared with the measurements from the CARES and CalNex campaigns. The main findings about the modeling sensitivity to the land surface schemes and vegetation distributions include

- The WRF-Chem simulation with the CLM4 land surface scheme and the MEGAN v2.0 module (Mv20CLM) produces similar biogenic isoprene and monoterpene emissions in terms of spatial patterns, magnitudes and diurnal variations as the one with the Noah land surface scheme (Mv20Noah) in June over California. The similarity in the biogenic emissions between the experiments using two different land schemes is primarily because of using MEGAN v2.0 and the same vegetation map in the two experiments. The spatial patterns and magnitudes of surface isoprene + MVK + MACR and monoterpene mixing ratios are generally similar between the two experiments with the Noah and CLM4 land surface schemes, although there are significant differences at some specific locations due to their differences in the near-surface meteorology such as surface net radiation and temperature. Compared with surface and aircraft measurements, both experiments generally underestimate the daytime mixing ratios of isoprene + MVK + MACR but overestimate the nighttime mixing ratios of monoterpenes.

- The experiments with the four vegetation data sets result in much larger differences in biogenic isoprene and monoterpene emissions than the ones with the two land surface schemes. The simulated total biogenic isoprene and monoterpene emissions over California can differ by a factor of 3 among the experiments and the difference can be even larger over specific locations. The comparison of mixing ratios of isoprene + MVK + MACR and monoterpenes with the observations indicates the simulation biases can be largely reduced with accurate vegetation distributions over some regions of California. For example, at an observation site at the forested foothills of Sierra Nevada, two experiments with the vegetation distributions from the USGS and VEG3 data sets capture the observed daytime surface mixing ratios of isoprene + MVK + MACR well, with values that are much larger than the experiments with the other two vegetation data sets.

- Although vegetation distributions from some data sets do significantly improve the model performance in simulating BVOC mixing ratios more than others, the optimal vegetation data set cannot be determined, because the improvement by vegetation data sets depends on 
both the region and BVOC species of interest. For example, over the Central Valley, the experiments with the VEG1 and VEG3 vegetation data sets simulate isoprene + MVK + MACR mixing ratios that are much closer to observations than the USGS and VEG2 data sets, while the VEG3 data set significantly underestimates the observed monoterpene mixing ratios. Large biases over some regions of California in all the experiments with current vegetation data sets imply that more effort is needed to improve land cover data sets and/or biogenic emission factors.

There are still some large biases existing over some regions of California regardless of the vegetation distributions. For example, all the experiments significantly underestimate the observed isoprene + MVK + MACR mixing ratios below an altitude of $1 \mathrm{~km}$ over the forest-covered Sierra Nevada. Over the Pasadena area, all the experiments simulate significantly smaller monoterpene mixing ratios than observed. The biases in BVOCs identified in this study may be partly due to inaccurate vegetation distributions in all the vegetation distribution data sets. The biases can also result from the uncertainties in BVOC emission factors for the individual types of vegetation commonly found in California. The constraints on BVOC emission factors applied in models are limited due to sparse measurements of BVOC emission fluxes. The MEGAN scheme in WRF-Chem uses the global-averaged emission factors for BVOC emissions for each PFT. Over California, the broadleaf temperate trees are primarily oaks that have relatively higher BVOC emission factors compared to the global mean values for temperate broadleaf trees. In addition, the needleleaf trees are pines that have relatively larger monoterpene emission factors compared to global mean values. These biases in emission factors may partly explain why all the experiments generally underestimate mixing ratios of isoprene + MVK + MACR and monoterpenes over the regions with large amounts of trees. The MEGAN scheme using the location-specified emission factor maps that accounts for species composition of trees may provide a better estimate on regional scales.

This study demonstrates large difference between the experiments with the two versions of MEGAN (v2.0 vs. v2.1), and that MEGAN v2.1 results in a better comparison with the observations over some parts of the study domain. However, this difference should not be fully attributed to the improvement of MEGAN between the two versions, because the two versions also use different vegetation distributions. The results highlight the importance of sub-grid vegetation distributions in simulating biogenic emissions even at a relatively high horizontal grid spacing (e.g., $4 \mathrm{~km}$ in this study). The biogenic emissions can be significantly different even though the dominant vegetation within a model grid box is similar. The comparison of the simulations and the observations at the surface sites and along the aircraft tracks reflects the large spatial variability of biogenic emissions and BVOC mixing ratios over California. It is challenging for model to capture such a spatial heterogeneity of BVOCs if the vegetation distributions are not appropriately represented in the simulation. The relatively large LOD of instruments on the aircrafts for monoterpenes compared to the true concentrations also make the evaluation of simulated monoterpenes difficult. Over a region with relatively low monoterpene concentrations, an instrument with lower LOD is needed. It is also noteworthy that this study is in a relatively dry and warm season; therefore, the impact of biogenic emission treatments may change for other seasons and during periods with higher cloudiness. A multiple-season investigation may be needed in the future. Finally, it is also noteworthy that factors other than biogenic emissions can influence the simulated BVOC mixing ratios over California, such as anthropogenic emissions and the oxidation mechanism of BVOCs used in simulations. Therefore, additional direct measurements of biogenic emission fluxes are needed for a better evaluation of simulated BVOC fluxes.

\section{Code availability}

The WRF-Chem version 3.5.1 release can be obtained at http://www2.mmm.ucar.edu/wrf/users/download/get_ source.html. Code modifications for implementing MEGANv2.1 into CLM are available upon request by contacting the corresponding author and will be released to public WRF-Chem version.

Acknowledgements. This work was supported by the U.S. Department of Energy, Office of Science, Office of Biological and Environmental Research's Atmospheric Systems Research (ASR) Program and Atmospheric Radiation Measurement (ARM) Climate Research Facility. A portion of this research was supported by the US NOAA's Atmospheric Composition and Climate Program (NA11OAR4310160). The simulations required for this work were performed on the National Energy Research Scientific Computing Center, supported by the Office of Science of the U.S. Department of Energy. We acknowledge Tom Jobson and Bentram Knighton for their measurements during the CARES campaign. The Pacific Northwest National Laboratory is operated for DOE by Battelle Memorial Institute under contract DE-AC05-76RL01830. NCAR is operated by the University Corporation of Atmospheric Research under sponsorship of the National Science Foundation.

Edited by: G. A. Folberth

\section{References}

Andreae, M. and Crutzen, P. J.: Atmospheric Aerosols: Biogeochemical Sources and Role in Atmospheric Chemistry, Science, 276, 1052-1058, doi:10.1126/science.276.5315.1052, 1997.

Arneth, A., Niinemets, Ü., Pressley, S., Bäck, J., Hari, P., Karl, T., Noe, S., Prentice, I. C., Serça, D., Hickler, T., Wolf, A., and Smith, B.: Process-based estimates of terrestrial ecosystem isoprene emissions: incorporating the effects of a di- 
rect $\mathrm{CO}_{2}$-isoprene interaction, Atmos. Chem. Phys., 7, 31-53, doi:10.5194/acp-7-31-2007, 2007.

Arneth, A., Harrison, S. P., Zaehle, S., Tsigaridis, K., Menon, S., Bartlein, P. J., Feichter, J., Korhola, A., Kulmala, M., O’Donnell, D., Schurgers, G., Sorvari, S., and Vesala, T.: Terrestrial biogeochemical feedbacks in the climate system, Nat. Geosci., 3, 525532, 2010.

Barlage, M., Chen, F., Tewari, M., Ikeda, K., Gochis, D., Dudhia, J., Rasmussen, R., Livneh, B., Ek, M., and Mitchell, K.: Noah land surface model modifications to improve snowpack prediction in the Colorado Rocky Mountains, J. Geophys. Res., 115, D22101, doi:10.1029/2009JD013470, 2010.

Bonan, G. B.: A land surface model (LSM ver. 1.0) for ecological, hydrological, and atmospheric studies: Technical description and user's guide, NCAR Tech. Note 4171STR, 150 pp., available at: http://opensky.ucar.edu/islandora/object/technotes: 185 (last access: 25 May 2016), 1996.

Bonan, G. B., Oleson, K. W., Vertenstein, M., Levis, S., Zeng, X., Dai, Y., Dickinson, R. E., and Yang, Z.-L.: The Land Surface Climatology of the Community Land Model Coupled to the NCAR Community Climate Model, J. Climate, 15, 3123-3149, doi:10.1175/1520-0442(2002)015<3123:TLSCOT>2.0.CO;2, 2002.

Carter, W. P. L.: Documentation of the SAPRC-99 Chemical Mechanism for VOC Reactivity Assessment, Draft report to the California Air Resources Board, Contracts 92-329 and 95-308, 8 May, available at: http://www.cert.ucr.edu/ carter/pubs/ (last access: 25 May 2016), 2000a.

Carter, W. P. L.: Implementation of the SAPRC-99 Chemical Mechanism into the Models-3 Framework, Report to the United States Environmental Protection Agency, 29 January, available at: http://www.cert.ucr.edu/ carter/pubs/ (last access: 1 December 2015), 2000b.

Chameides, W. L., Fehsenfeld, F., Rodgers, M. O., Cardelino, C., Martinez, J., Parrish, D., Lonneman, W., Lawson, D. R., Rasmussen, R. A., Zimmerman, P., Greenberg, J., Mlddleton, P., and Wang, T.: Ozone precursor relationships in the ambient atmosphere, J. Geophys. Res., 97, 6037-6055, doi:10.1029/91JD03014, 1992.

Claeys, M., Graham, B., Vas, G., Wang, W., Vermeylen, R., Pashynska, V., Cafmeyer, J., Guyon, P., Andreae, M. O., Artaxo, P., and Maenhaut, W.: Formation of Secondary Organic Aerosols Through Photooxidation of Isoprene, Science, 303, 1173-1176, doi:10.1126/science.1092805, 2004.

Cox, P., Delao, A., Komorniczak, A., and Weller, R.: The California almanac of emissions and air quality 2009 edition, available at: http://www.arb.ca.gov/aqd/almanac/almanac09/almanac2009all. pdf (last access: May 2016), 2009.

Dickinson, R. E.: Land Surface Processes and Climate Surface Albedos and Energy-Balance, Adv. Geophys., 25, 305-353, doi:10.1016/S0065-2687(08)60176-4, 1983.

Duhl, T. R., Guenther, A., and Helmig, D.: Estimating urban vegetation cover fraction using Google Earth ${ }^{\circledR}$ images, Journal of Land Use Science, 7, 311-329, doi:10.1080/1747423X.2011.587207, 2012.

Fast, J. D, Gustafson Jr., W. I., Easter, R. C., Zaveri, R. A., Barnard, J. C., Chapman, E. G., and. Grell, G. A.: Evolution of ozone, particulates, and aerosol direct forcing in an urban area using a new fully-coupled meteorology, chemistry, and aerosol model, J. Geophys. Res., 111, D21305, doi:10.1029/2005JD006721, 2006. Fast, J. D., Allan, J., Bahreini, R., Craven, J., Emmons, L., Ferrare, R., Hayes, P. L., Hodzic, A., Holloway, J., Hostetler, C., Jimenez, J. L., Jonsson, H., Liu, S., Liu, Y., Metcalf, A., Middlebrook, A., Nowak, J., Pekour, M., Perring, A., Russell, L., Sedlacek, A., Seinfeld, J., Setyan, A., Shilling, J., Shrivastava, M., Springston, S., Song, C., Subramanian, R., Taylor, J. W., Vinoj, V., Yang, Q., Zaveri, R. A., and Zhang, Q.: Modeling regional aerosol and aerosol precursor variability over California and its sensitivity to emissions and long-range transport during the 2010 CalNex and CARES campaigns, Atmos. Chem. Phys., 14, 10013-10060, doi:10.5194/acp-14-10013-2014, 2014.

Fehsenfeld, F., Calvert, J., Fall, R., Goldan, P., Guenther, A. B., Hewitt, C. N., Lamb, B., Liu, S., Trainer, M., Westberg, H., and Zimmerman, P.: Emissions of volatile organic compounds from vegetation and the implications for atmospheric chemistry, Global Biogeochem. Cy., 6, 389-430, doi:10.1029/92GB02125, 1992.

Gao, Y., Liu, X., Zhao, C., and Zhang, M.: Emission controls versus meteorological conditions in determining aerosol concentrations in Beijing during the 2008 Olympic Games, Atmos. Chem. Phys., 11, 12437-12451, doi:10.5194/acp-11-12437-2011, 2011.

Gao, Y., Zhao, C., Liu, X., Zhang, M., and Leung, L. R.: Regional modeling of aerosol and its radiative forcing over East Asia using WRF-Chem, Atmos. Environ., 92, 250-266, 2014.

Gentner, D. R., Isaacman, G., Worton, D. R., Chan, A. W. H., Dallmann, T. R., Davis, L., Liu, S., Day, D. A., Russell, L. M., Wilson, K. R., Weber, R., Guha, A., Harley, R. A., and Goldstein, A. H.: Elucidating secondary organic aerosol from diesel and gasoline vehicles through detailed characterization of organic carbon emissions, P. Natl. Acad. Sci. USA, 109, 18318-18323, doi:10.1073/pnas.1212272109, 2012.

Greenfield, E. J., Nowak, D. J., and Walton, J. T.: Assessment of 2001 NLCD percent tree and impervious cover estimates, Photogramm. Eng. Rem. S., 75, 1279-1286, 2009.

Grell, G. A., Peckham, S. E., Schmitz, R., McKeen, S. A., Frost, G., Skamarock, W. C., and Eder, B.: Fully coupled "online" chemistry within the WRF model, Atmos. Environ., 39, 6957-6976, 2005.

Guenther, A., Karl, T., Harley, P., Wiedinmyer, C., Palmer, P. I., and Geron, C.: Estimates of global terrestrial isoprene emissions using MEGAN (Model of Emissions of Gases and Aerosols from Nature), Atmos. Chem. Phys., 6, 3181-3210, doi:10.5194/acp-63181-2006, 2006.

Guenther, A. B.: Biological and chemical diversity of biogenic volatile organic emissions into the atmosphere, ISRN Atmospheric Sciences, 2013, 786290, doi:10.1155/2013/786290, 2013.

Guenther, A. B., Hewitt, C. N., Erickson, D., Fall, R., Geron, C., Graedel, T., Harley, P., Klinger, L., Lerdau, M., McKay, W. A., Pierce, T., Scholes, B., Steinbrecher, R., Tallamraju, R., Taylor, J., and Zimmerman, P.: A global model of natural volatile organic compound emissions, J. Geophys. Res.-Atmos., 100, 8873-8892, 1995.

Guenther, A. B., Jiang, X., Heald, C. L., Sakulyanontvittaya, T., Duhl, T., Emmons, L. K., and Wang, X.: The Model of Emissions of Gases and Aerosols from Nature version 2.1 (MEGAN2.1): an extended and updated framework for modeling biogenic emis- 
sions, Geosci. Model Dev., 5, 1471-1492, doi:10.5194/gmd-51471-2012, 2012.

Hijmas, R. J., Cameron, S. E., Parra, J. L., Jones, P. G., and Jarvis, A.: Very high resolution interpolated climate surfaces for global land areas, Int. J. Climatol., 25, 1965-1978, doi:10.1002/joc.1276, 2005.

Homer, C., Huang, C., Yang, L., Wylie, B., and Coan, M.: Development of a 2001 National Landcover Database for the United States, Photogramm. Eng. Rem. S., 70, 829-840, 2004.

Hong, S.-Y., Noh, Y., and Dudhia, J.: A new vertical diffusion package with an explicit treatment of entrainment processes, Mon. Weather Rev., 134, 2318-2341, 2006.

Huang, M., Carmichael, G. R., Spak, S. N., Adhikary, B., Kulkarni, S., Cheng, Y., Wei, C., Tang, Y., D’Allura, A., Wennberg, P. O., Huey, G. L., Dibb, J. E., Jimenez, J. L., Cubison, M. J., Weinheimer, A. J., Kaduwela, A., Cai, C., Wong, M., Bradley Pierce, R., Al-Saadi, J. A., Streets, D. G., and Zhang, Q.: Multi-scale modeling study of the source contributions to nearsurface ozone and sulfur oxides levels over California during the ARCTAS-CARB period, Atmos. Chem. Phys., 11, 3173-3194, doi:10.5194/acp-11-3173-2011, 2011.

Iacono, M. J., Delamere, J. S., Mlawer, E. J., Shephard, M. W., Clough, S. A., and Collins, W. D.: Radiative forcing by long-lived greenhouse gases: Calculations with the AER radiative transfer models, J. Geophys. Res., 113, D13103, doi:10.1029/2008JD009944, 2008.

Jin, J. and Miller, N. L.: Analysis of the impact of snow on dailyweather variability in mountainous regions using MM5, J. Hydrometeorol., 8, 245-258, doi:10.1175/JHM565.1, 2007.

Jin, J. and Wen, L.: Evaluation of snowmelt simulation in the Weather Research and Forecasting model, J. Geophys. Res., 117, D10110, doi:10.1029/2011JD016980, 2012.

Kain, J. S.: The Kain-Fritsch convective parameterization: An update, J. Appl. Meteorol., 43, 170-181, 2004.

Ke, Y., Leung, L. R., Huang, M., Coleman, A. M., Li, H., and Wigmosta, M. S.: Development of high resolution land surface parameters for the Community Land Model, Geosci. Model Dev., 5, 1341-1362, doi:10.5194/gmd-5-1341-2012, 2012.

Knote, C., Hodzic, A., Jimenez, J. L., Volkamer, R., Orlando, J. J., Baidar, S., Brioude, J., Fast, J., Gentner, D. R., Goldstein, A. H., Hayes, P. L., Knighton, W. B., Oetjen, H., Setyan, A., Stark, H., Thalman, R., Tyndall, G., Washenfelder, R., Waxman, E., and Zhang, Q.: Simulation of semi-explicit mechanisms of SOA formation from glyoxal in aerosol in a 3-D model, Atmos. Chem. Phys., 14, 6213-6239, doi:10.5194/acp-14-6213-2014, 2014.

Lamb, B., Guenther, A., Gay, D., and Westberg, H.: A national inventory of biogenic hydrocarbon emissions. Atmos. Environ., 21, 1695-1705, doi:10.1016/0004-6981(87)90108-9, 1987.

Lawrence, D. M., Oleson, K. W., Flanner, M. G., Thornton, P. E., Swenson, S. C., Lawrence, P. J., Zeng, X., Yang, Z.-L., Levis, S., Sakaguchi, K., Bonan, G. B., and Slater, A. G.: Parameterization improvements and functional and structural advances in version 4 of the Community Land Model. J. Adv. Model. Earth Sys., 3, M03001, doi:10.1029/2011MS000045, 2011.

Lawrence, P. J. and Chase, T. N.: Climate Impacts. Our earth's changing land: an encyclopedia of land-use and land-cover change, H. Geist, Greenwood Press, Westport, USA, 115-124, 2006.
Lawrence, P. J. and Chase, T. N.: Representing a new MODIS consistent land surface in the Community Land Model (CLM 3.0), J. Geophys. Res.-Biogeosci., 112, G01023, doi:10.1029/2006JG000168, 2007.

LeMone, M. A., Chen, F., Tewari, M., Dudhia, J., Geerts, B., Miao, Q., Coulter, R. L., and Grossman, R. L.: Simulating the IHOP_2002 Fair-Weather CBL with the WRF-ARW-Noah modeling system. Part I: Surface fluxes and CBL structure and evolution along the eastern track, Mon. Weather Rev., 138, 722-744, doi:10.1175/2009mwr3003.1, 2010a.

LeMone, M. A., Chen, F., Tewari, M., Dudhia, J., Geerts, B., Mia, Q., Coulter, R. L., and Grossman, R. L.: Simulating the IHOP_2002 Fair-Weather CBL with the WRF-ARW Noah modeling system. Part II: Structures from a few kilometers to $100 \mathrm{~km}$ across, Mon. Weather Rev., 138, 745-764, doi:10.1175/2009mwr3004.1, 2010b.

Lindinger, W., Hansel, A., and Jordan, A.: On-line monitoring of volatile organic compounds at pptv levels by means of protontransfer-reaction mass spectrometry (PTR-MS) - medical applications, food control and environmental research, Int. J. Mass Spectrom., 173, 191-241, 1998.

McKeen, S. A., Wotawa, G., Parrish, D. D., Holloway, J. S., Buhr, M. P., Hubler, G., Fehsenfeld, F. C., and Meagher, J. F.: Ozone production from Canadian wildfires during June and July of 1995, J. Geophys. Res., 107, 4192, doi:10.1029/2001JD000697, 2002.

Morrison, H., Thompson, G., and Tatarskii, V.: Impact of Cloud Microphysics on the Development of Trailing Stratiform Precipitation in a Simulated Squall Line: Comparison of One- and TwoMoment Schemes, Mon. Weather Rev., 137, 991-1007, 2009.

Müller, J.-F.: Geographical distribution and seasonal variation of surface emissions and deposition velocities of atmospheric trace gases, J. Geophys. Res., 97, 3787-3804, 1992.

Niinemets, Ü., Tenhunen, J. D., Harley, P. C., and Steinbrecher, R.: A model of isoprene emission based on energetic requirements for isoprene synthesis and leaf photosynthetic properties for Liquidambar and Quercus, Plant Cell Environ., 22, 13191335, 1999.

Niinemets, Ü., Seufert, G., Steinbrecher, R., and Tenhunen, J. D.: A model coupling foliar monoterpene emissions to leaf photosynthetic characteristics in Mediterranean evergreen Quercus species, New Phytol., 153, 257-275, 2002.

Oleson, K. W., Lawrence, D. M., Bonan, G. B., Flanner, M. G., Kluzek, E., Lawrence, P. J., Levis, S., Swenson, S. C., Thornton, P. E., Dai, A., Decker, M., Dickinson, R., Feddema, J., Heald, C. L., Hoffman, F., Lamarque, J.-F., Mahowald, N., Niu, G.-Y., Qian, T., Randerson, J., Running, S., Sakaguchi, K., Slater, A., Stöckli, R., Wang, A., Yang, Z.-L., Zeng, X., and Zeng, X.: Technical Description of version 4.0 of the Community Land Model (CLM), Tech. Rep. NCAR/TN$478+$ STR, National Center for Atmospheric Research, available at: http://www.cesm.ucar.edu/models/cesm1.0/clm/CLM4_ Tech_Note.pdf (last access: 25 May 2016), 2010.

Paulson, C. A.: The mathematical representation of wind speed and temperature profiles in the unstable atmospheric surface layer, J. Appl. Meteorol., 9, 857-861, 1970.

Pfister, G. G., Parrish, D. D., Worden, H., Emmons, L. K., Edwards, D. P., Wiedinmyer, C., Diskin, G. S., Huey, G., Oltmans, S. J., Thouret, V., Weinheimer, A., and Wisthaler, A.: Characterizing 
summertime chemical boundary conditions for airmasses entering the US West Coast, Atmos. Chem. Phys., 11, 1769-1790, doi:10.5194/acp-11-1769-2011, 2011.

Pierce, T., Geron, C., Bender, L., Dennis, R., Tonnesen, G., and Guenther, A.: Influence of increased isoprene emissions on regional ozone modeling, J. Geophys. Res., 103, 25611-25629, doi:10.1029/98JD01804, 1998.

Poisson, N., Kanakidou, M., and Crutzen, P. J.: Impact of NonMethane Hydrocarbons on Tropospheric Chemistry and the Oxidizing Power of the Global Troposphere: 3-Dimensional Modelling Results, J. Atmos. Chem., 36, 157-230, 2000.

Rasmussen, R. A.: What do the hydrocarbons from trees contribute to air pollution? J. Air Poll. Con. Asso., 22, 7, 537-543, 1972.

Ryerson, T. B., Andrews, A. E., Angevine, W. M., Bates, T. S., Brock, C. A., Cairns, B., Cohen, R. C., Cooper, O. R., de Gouw, J. A., Fehsenfeld, R. C., Ferrare, R. A., Fischer, M. L., Flagan, R. C., Goldstein, A. H., Hair, J. W., Hardesty, R. M., Hostetler, C. A., Jimenez, J. L., Langford, A. O., McCauley, E., McKeen, S. A., Molina, L. T., Nenes, A., Oltmans, S. J., Parrish, D. D., Pederson, J. R., Pierce, R. B., Prather, K., Quinn, P. K., Seinfeld, J. H., Senff, C. J., Sorooshian, A., Stutz, J., Surratt, J. D., Trainer, M., Volkamer, R., Williams, E. J., and Wofsy, S. C.: The 2010 California Research at the Nexus of Air Quality and Climate Change (CalNex) field study, J. Geophys. Res., 118, 58305866, doi:10.1002/jgrd.50331, 2013.

Sakulyanontvittaya, T., Duhl, T., Wiedinmyer, C., Helmig, D., Matsunaga, S., Potosnak, M., Milford, J., and Guenther, A.: Monoterpene and sesquiterpene emission estimates for the United States, Environ. Sci. Technol., 42, 1623-1629, 2008.

Sanderson, M. G., Jones, C. D., Collins, W. J., Johnson, C. E., and Derwent, R. G.: Effect of Climate Change on Isoprene Emissions and Surface Ozone Levels, Geophys. Res. Lett., 30, 1936, doi:10.1029/2003GL017642, 2003.

Schurgers, G., Arneth, A., Holzinger, R., and Goldstein, A. H.: Process-based modelling of biogenic monoterpene emissions combining production and release from storage, Atmos. Chem. Phys., 9, 3409-3423, doi:10.5194/acp-9-3409-2009, 2009.

Shilling, J. E., Zaveri, R. A., Fast, J. D., Kleinman, L., Alexander, M. L., Canagaratna, M. R., Fortner, E., Hubbe, J. M., Jayne, J. T., Sedlacek, A., Setyan, A., Springston, S., Worsnop, D. R., and Zhang, Q.: Enhanced SOA formation from mixed anthropogenic and biogenic emissions during the CARES campaign, Atmos. Chem. Phys., 13, 2091-2113, doi:10.5194/acp-13-20912013, 2013.

Shrivastava, M., Fast, J., Easter, R., Gustafson Jr., W. I., Zaveri, R. A., Jimenez, J. L., Saide, P., and Hodzic, A.: Modeling organic aerosols in a megacity: comparison of simple and complex representations of the volatility basis set approach, Atmos. Chem. Phys., 11, 6639-6662, doi:10.5194/acp-11-6639-2011, 2011.

Shrivastava, M. K. B., Zelenyuk, A., Imre, D., Easter Jr., R. C., Beranek, J., Zaveri, R. A., and Fast, J. D.: Implications of Low Volatility SOA and Gas-Phase Fragmentation Reactions on SOA Loadings and their Spatial and Temporal Evolution in the Atmosphere, J. Geophys. Res.-Atmos., 118, 3328-3342, doi:10.1002/jgrd.50160, 2013.

Stauffer, D. R. and Seaman, N. L.: Use of four-dimensional data assimilation in a limited-area mesoscale model, Part I: Experiments with synoptic-scale data, Mon. Weather Rev., 118, 1250-1277, 1990.
Still, C. J., Berry, J. A., Collatz, G. J., and DeFries, R. S.: Global distribution of $\mathrm{C}_{3}$ and $\mathrm{C}_{4}$ vegetation: Carbon cycle implications, Global Biogeochem. Cy., 17, 1006, doi:10.1029/2001GB001807, 2003.

Went, F. W.: Blue hazes in the atmosphere, Nature, 187, 641-643, 1960.

Wild, O., Zhu, X., and Prather, M. J.: Fast-J: Accurate simulation of in- and below-cloud photolysis in tropospheric chemical models, J. Atmos. Chem., 37, 245-282, doi:10.1023/A:1006415919030, 2000.

Willmott, C. J. and Matsuura, K.: Terrestrial Air Temperature and Precipitation: Monthly and Annual Time Series (1950-1999), available at: http://climate.geog.udel.edu/ climate/html_pages/ README.ghcn_ts2.html (last access: May 2016), 2011.

Zaveri, R. A., Shaw, W. J., Cziczo, D. J., Schmid, B., Ferrare, R. A., Alexander, M. L., Alexandrov, M., Alvarez, R. J., Arnott, W. P., Atkinson, D. B., Baidar, S., Banta, R. M., Barnard, J. C., Beranek, J., Berg, L. K., Brechtel, F., Brewer, W. A., Cahill, J. F., Cairns, B., Cappa, C. D., Chand, D., China, S., Comstock, J. M., Dubey, M. K., Easter, R. C., Erickson, M. H., Fast, J. D., Floerchinger, C., Flowers, B. A., Fortner, E., Gaffney, J. S., Gilles, M. K., Gorkowski, K., Gustafson, W. I., Gyawali, M., Hair, J., Hardesty, R. M., Harworth, J. W., Herndon, S., Hiranuma, N., Hostetler, C., Hubbe, J. M., Jayne, J. T., Jeong, H., Jobson, B. T., Kassianov, E. I., Kleinman, L. I., Kluzek, C., Knighton, B., Kolesar, K. R., Kuang, C., Kubátová, A., Langford, A. O., Laskin, A., Laulainen, N., Marchbanks, R. D., Mazzoleni, C., Mei, F., Moffet, R. C., Nelson, D., Obland, M. D., Oetjen, H., Onasch, T. B., Ortega, I., Ottaviani, M., Pekour, M., Prather, K. A., Radney, J. G., Rogers, R. R., Sandberg, S. P., Sedlacek, A., Senff, C. J., Senum, G., Setyan, A., Shilling, J. E., Shrivastava, M., Song, C., Springston, S. R., Subramanian, R., Suski, K., Tomlinson, J., Volkamer, R., Wallace, H. W., Wang, J., Weickmann, A. M., Worsnop, D. R., Yu, X.-Y., Zelenyuk, A., and Zhang, Q.: Overview of the 2010 Carbonaceous Aerosols and Radiative Effects Study (CARES), Atmos. Chem. Phys., 12, 7647-7687, doi:10.5194/acp-12-7647-2012, 2012.

Zeng, X., Shaikh, M., Dai, Y., Dickinson, R. E., and Myneni, R.: Coupling of the common land model to the NCAR community climate model, J. Climate, 15, 1832-1854, doi:10.1175/15200442(2002)015<1832:COTCLM>2.0.CO;2, 2002.

Zhao, C., Hu, Z., Qian, Y., Ruby Leung, L., Huang, J., Huang, M., Jin, J., Flanner, M. G., Zhang, R., Wang, H., Yan, H., Lu, Z., and Streets, D. G.: Simulating black carbon and dust and their radiative forcing in seasonal snow: a case study over North China with field campaign measurements, Atmos. Chem. Phys., 14, 1147511491, doi:10.5194/acp-14-11475-2014, 2014.

Zimmerman, P.: Testing of hydrocarbon emissions from vegetation, leaf litter and aquatic surfaces and development of a method for compiling biogenic emission inventories, Tech. Rep. EPA-4504-70-004, U.S. Environmental Protection Agency, Research Triangle Park, California, USA, 1979.

Zimmerman, P. R., Chatfield, R. B., Fishman, J., Crutzen, P. J., and Hanst, P. L.: Estimates the production of $\mathrm{CO}$ and $\mathrm{H}_{2}$ from the oxidation of hydrocarbon emissions from vegetation, Geophys. Res. Lett., 5, 679-682, 1978. 